\title{
Synthesis of New Porphyrin-Fullerene Dyads Capable of Forming Charge-Separated States on a Microsecond Lifetime Scale
}

\author{
Alexander S. Konev, ${ }^{*[a]}$ Alexander F. Khlebnikov, ${ }^{*[a]}$ Pavel I. Prolubnikov, ${ }^{[a]}$ \\ Andrey S. Mereshchenko, ${ }^{[a]}$ Alexey V. Povolotskiy, ${ }^{[a]}$ Oleg V. Levin, ${ }^{[a]}$ and Andreas Hirsch ${ }^{*[b]}$
}

Abstract: A series of covalently linked axially symmetric porphyrin-fullerene dyads with a rigid pyrrolo[3,4-c]pyrrolic linker enabling a fixed and orthogonal arrangement of the chromophores has been synthesized and studied by means of transient absorption spectroscopy and cyclic voltammetry. The lifetime of the charge-separated state has been found to depend on the substituents on the porphyrin core, reach- ing up to $4 \mu \mathrm{s}$ for a species with meso- $\left(p-\mathrm{MeOC}_{6} \mathrm{H}_{4}\right)$ substituents. The ground and excited electronic states of model compounds have been calculated at the DFT and TD-DFT B3LYP(6-31G(d)) levels of theory and analyzed with regard to the effect of the substituent on the stabilization of the charge-separated state in the porphyrin-fullerene ensemble with a view to explaining the observed dependence.

\section{Introduction}

Porphyrin-fullerenes are often cited as promising materials for artificial photosynthesis ${ }^{[1]}$ and for the construction of organic photovoltaic devices. ${ }^{[1,2]}$ Electron transfer from the porphyrin moiety to the fullerene core, which takes places in a sequence of relaxation processes after consumption of an electromagnetic energy quantum by the molecule, leads to the formation of a charge-separated (CS) state and represents the key process in the transformation of solar energy. ${ }^{[16,3]}$ Hence, the assembly of new compounds with a long lifetime of the chargeseparated state is one of the main aims in the development of this field. ${ }^{[1 b, d, 4]}$ The theoretical expression for the lifetime of the CS state, which is defined as the inverse rate constant of the back-electron-transfer (charge recombination) process, is given in Marcus theory and depends on the reorganization energy, the Gibbs free energy for charge recombination, and electronic coupling of the interacting chromophores. ${ }^{[5]}$ To date, some of the values it contains, such as the internal term for reorganization energy and the electronic coupling integral, have proved quite difficult if not impossible to calculate for a given structure in advance, without experimental data, although some

[a] Dr. A. S. Konev, Prof. Dr. A. F. Khlebnikov, P. I. Prolubnikov,

Dr. A. S. Mereshchenko, Dr. A. V. Povolotskiy, Dr. O. V. Levin

Institute of Chemistry, St. Petersburg State University

Universiteskii pr. 26, Petrodvorets

198504, St. Petersburg (Russian Federation)

E-mail:a.konev@spbu.ru

alexander.khlebnikov@pobox.spbu.ru

[b] Prof. Dr. A. Hirsch

Institute of Organic Chemistry II

Friedrich-Alexander Universität Erlangen Nürnberg

Henkestrasse 42, 91054 Erlangen (Germany)

E-mail: andreas.hirsch@fau.de

Supporting information for this article is available on the WWW under http://dx.doi.org/10.1002/chem.201404435. reasonable estimates can be made when model compounds are available for experimental study. ${ }^{[6]}$ However, the vast amount of literature published throughout the last two decades devoted to porphyrin-fullerene dyads allows some empirical rules to be formulated concerning the relationship between the structure of a given compound and the lifetime of the charge-separated state it may form. Thus, the effects of the inter-chromophoric distance, ${ }^{[1 c, 7]}$ the relative orientation of chromophores, ${ }^{[1 c, 7 a-c, 8]}$ the nature of the linker, ${ }^{[7 d-i, 9]}$ the role of the microenvironment of the porphyrin core, including the nature of central metal atom ${ }^{[9 b, 10]}$ and ligands bound to this atom, $^{[11]}$ the porphyrin substitution pattern, ${ }^{[12]}$ and the dendritic environment ${ }^{[13]}$ on the CS state lifetime have been studied and discussed in recent years.

The discussion presented in the above works, as well as the data given in these and other works cited below, allow the following conclusions to be deduced:

1) Close face-to-face alignment of $\mathrm{C}_{60}$ and porphyrin fragments favors both forward and back electron transfer, thus resulting in lifetimes of the CS state of $3.5 \mathrm{~ns}^{[\mathrm{8a}, 9 \mathrm{a}]}$ at most. ${ }^{[1,3 a, 8 b, 10,11,14,15]}$

2) All of the reported dyads capable of generating a longlived (microsecond range) CS state have either a large fixed separation of the chromophores ${ }^{[4 a, 7 f, i, 16]}$ or their face-toedge alignment, ${ }^{[1,8 b, 17]}$ leading to an orthogonal orientation of their $\pi$-systems. (It should also be mentioned that even longer CS state lifetimes have been reported in linear triads, tetrads, and other multi-component arrays. ${ }^{[1 b, c]}$ However, as the formation of long-lived CS states in these systems proceeds in a stepwise manner, through a sequence of charge separation/charge shift events, extension of the lifetime of the dyads comprising such multi-component arrays would certainly benefit the overall lifetime of the CS state of the system.) 
3) It is important to keep the inter-chromophoric separation fixed, as systems in which $\mathrm{C}_{60}$ and porphyrin moieties are connected via a flexible linker, which allows the chromophores to attain a close-contact face-to-face conformation, have shorter CS state lifetimes, from the picose$\operatorname{cond}^{[1 c, 3 a, 7 a, 8 a, 18]}$ to the nanosecond ${ }^{[1 c, 3 a, 7 b-e, 8 a, 13,18 c, 19]}$ range, $650 \mathrm{~ns}^{[19 f]}$ at most.

However, not all dyads with a large and fixed inter-chromophoric distance and/or a face-to-edge alignment of the chromophores are capable of generating a long-lived CS state. ${ }^{[7,8 a, 9 b, 20]}$ In some cases, the CS state is formed, but the electronic interaction between the chromophores is very effective due to an unbroken conjugation pathway between the $\pi$ systems of $\mathrm{C}_{60}$ and the porphyrin, which increases the rate of back-electron transfer. This is exemplified by polyacetylenelinked porphyrin-fullerene dyads. ${ }^{[9 b, 20 a]}$ Extension of the $\pi$ system of the porphyrin by acetylene bonds seems to be so effective that even when a pyrrolidine moiety is inserted between porphyrinylacetylene and $C_{60}{ }^{[7 g, 20 b]}$ the interaction of the respective $\pi$-systems is still significant and facilitates backelectron transfer. In other cases, formation of the CS state can be prevented due to a competing intramolecular process of relaxation from the porphyrin-centered singlet excited state to a $\mathrm{C}_{60}$-centered triplet state, known as energy transfer. ${ }^{[8 a]}$

The following strategy can thus be formulated for the development of porphyrin-fullerene dyads capable of forming long-lived CS states: the molecule should have a fixed, large inter-chromophoric distance, direct conjugation of the chromophores should be avoided, the alignment of the chromophores should be approximately face-to-edge, and the energy of the CS state should be lowered to reduce the relative rates of competitive processes. The ways to accomplish the first two tasks are quite clear, whereas the factors governing the energy of the CS state are not so obvious. The search for ways to stabilize the CS state is still quite an important task.

We have recently synthesized an axially symmetric porphyrin-fullerene dyad $\mathbf{1}$ a (Scheme 1) that meets the structural requirements of the above strategy, and have shown that thermodynamically it is capable of forming a charge-separated state. ${ }^{[6 b]}$ In the present work, we report an alternative approach for the synthesis of $\mathbf{1} \mathbf{a}$ and substituted analogues $\mathbf{1} \mathbf{b}-\mathbf{d}$ (Scheme 1), and photophysical studies of these compounds. The effect of substitution on the porphyrin on the stabilization of the CS state based on TD DFT quantum chemical calculations and the effect of this stabilization on the CS state lifetime in dyads $\mathbf{1} \mathbf{a}-\mathbf{d}$ are discussed.

\section{Results and Discussion}

\section{Synthesis}

The synthesis of compound $\mathbf{1}$ a that we reported previously ${ }^{[6 b]}$ required the use of a ten-fold excess of porphyrin $2 \mathrm{a}$ in one of the final steps (Scheme 1). Although unreacted porphyrin $\mathbf{2 a}$ could be recovered by chromatographic separation and

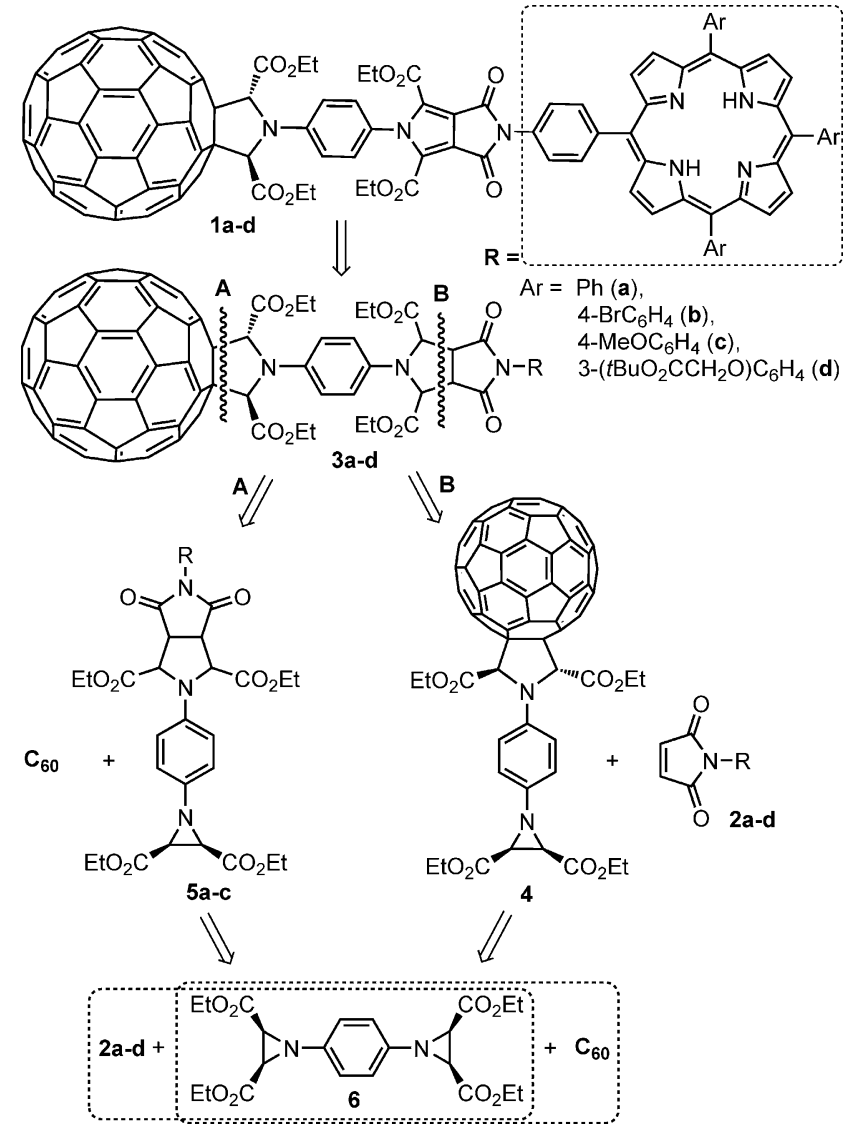

Scheme 1. Retrosynthetic disconnection of the target porphyrin-fullerenes 1 a-d.

reused, the large excess of this compound made the isolation of the intermediate cycloadducts $\mathbf{3} \mathbf{a}$ rather laborious. Consequently, we have attempted an alternative approach to the target compounds 1 in the present work. In this approach, instead of attaching fullerene-containing building block 4 to maleimido-substituted porphyrins $\mathbf{2}$, we decided to synthesize porphyrin-containing building blocks $\mathbf{5}$ from porphyrins $\mathbf{2}$ and bis-aziridine $\mathbf{6}$, and then react them with excess fullerene $C_{60}$ (Scheme 1). This should significantly expedite the synthesis of the target products as the oxidation process may be performed in a one-pot mode, without isolation of the intermediate cycloadducts. Besides, due to the significant differences in $R_{\mathrm{f}}$ of $\mathrm{C}_{60}$ and the target porphyrin-fullerenes $\mathbf{1}$, the chromatographic separation should be rendered much more convenient.

The required porphyrins 2 were obtained by an iodine-catalyzed condensation ${ }^{[21,6 b]}$ of pyrrole, aldehyde 7 , and the corresponding benzaldehydes $\mathbf{8} \mathbf{a}-\mathbf{d}$, followed by oxidation of the resulting porphyrinogen with chloranil (Scheme 2). It is known that the yield of the porphyrinogen in the condensation of pyrrole with aldehydes shows a bell-shaped dependence on the reaction time. ${ }^{[22]}$ To determine the optimal reaction time, we performed a series of experiments in which the reaction mixture containing the porphyrinogen was quenched with chloranil after certain time intervals and the resulting mixtures were analyzed by LC-MS (to determine the identity of the 


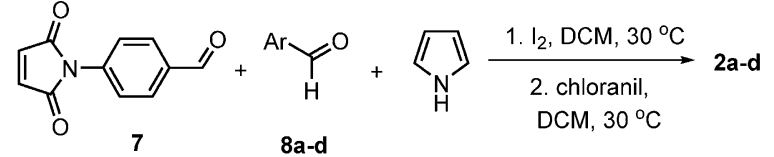

2, 8: $\mathrm{Ar}=\mathrm{Ph}(\mathbf{a}), 4-\mathrm{BrC}_{6} \mathrm{H}_{4}(\mathbf{b}), 4-\mathrm{MeOC}_{6} \mathrm{H}_{4}(\mathbf{c}), 3-\left(t \mathrm{BuO}_{2} \mathrm{CCH}_{2} \mathrm{O}\right) \mathrm{C}_{6} \mathrm{H}_{4}(\mathbf{d})$

Scheme 2. Synthesis of porphyrins $\mathbf{2}$ a-d.

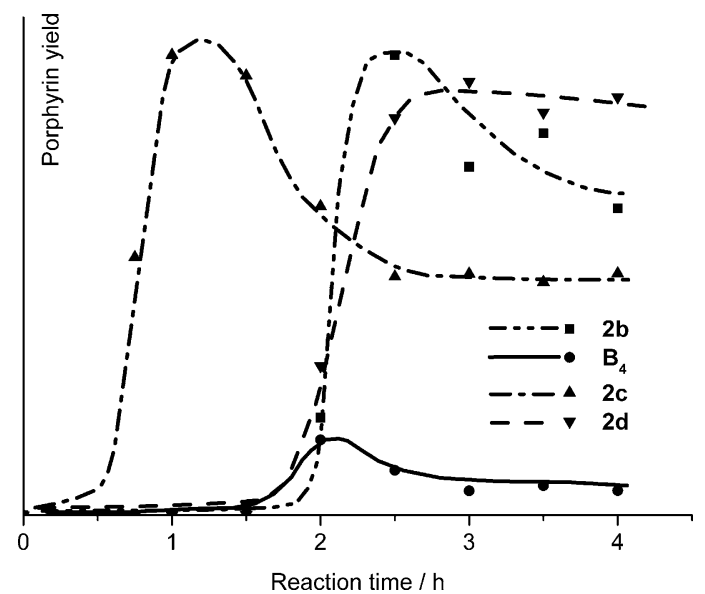

Figure 1. Dependence of the yields of porphyrins $\mathbf{2} \mathbf{b}-\mathbf{d}$ obtained from aldehydes $\mathbf{8} \mathbf{b}$ - $\mathbf{d}$ on the reaction time. The dependence for $\mathrm{B}_{4}$-porphyrin, where " $B$ " denotes the aryl fragment of aldehyde 7 , is given for the reaction with aldehyde $\mathbf{8} \mathbf{b}$. The graphs are scaled to allow visual comparison of data for different reactions. Unscaled graphs showing the dependence of yields on the reaction time for selected $A_{x} B_{y}$ porphyrins in these reactions are given in the Supporting Information. The experimental data are presented by markers, according to the legend on the diagram.

Table 1. Optimal reaction times and yields for the synthesis of porphyrins 2.

\begin{tabular}{llll|} 
& $\mathrm{Ar}$ & $\begin{array}{l}\text { Optimal } \\
\text { reaction time [h] }\end{array}$ & Yield [\%] \\
\hline $\mathbf{2 a}$ & $\mathrm{Ph}$ & $1-2^{[a]}$ & $12-16^{[\mathrm{a}]}$ \\
$\mathbf{2} \mathbf{b}$ & $4-\mathrm{BrC}_{6} \mathrm{H}_{4}$ & $2.5^{[\mathrm{b}]}$ & 17 \\
$\mathbf{2}$ & $4-\mathrm{MeOC}_{6} \mathrm{H}_{4}$ & $1.2^{[\mathrm{b}]}$ & 9 \\
$\mathbf{2 d}$ & $3-\left(t \mathrm{BuO}_{2} \mathrm{CCH}_{2} \mathrm{O}\right) \mathrm{C}_{6} \mathrm{H}_{4}$ & $3^{[\mathrm{b}]}$ & 10 \\
\hline
\end{tabular}

[a] Determined previously (ref. [6b]) by optimization of isolated yield. [b] Determined by HPLC.

peak) and HPLC (to determine the amount of each porphyrin). The results are presented in Figure 1 and summarized in Table 1.

As one can see from the presented data, electron-withdrawing substituents on the aryl group, such as $p$ - $\mathrm{Br}$ - and $m$-RO-, increased the reaction time for the condensation. The main reason for this seems to be the decreased Lewis basicity of the carbonyl oxygen in aldehydes $\mathbf{8} \mathbf{b}, \mathbf{d}$ compared to aldehyde $\mathbf{7}$. This significantly shifts the equilibrium between the $8: I_{2}$ and $7: I_{2}$ complexes to the $7: I_{2}$ side, resulting in preferred activation of aldehyde $\mathbf{7}$ compared to aldehydes $\mathbf{8} \mathbf{b}$ or $\mathbf{8} \mathbf{d}$ (Scheme 3). Consequently, pyrrole mainly reacts with the $7: I_{2}$ complex, leading to accumulation of the $\mathrm{B}_{4}$-type porphyrinogen in the

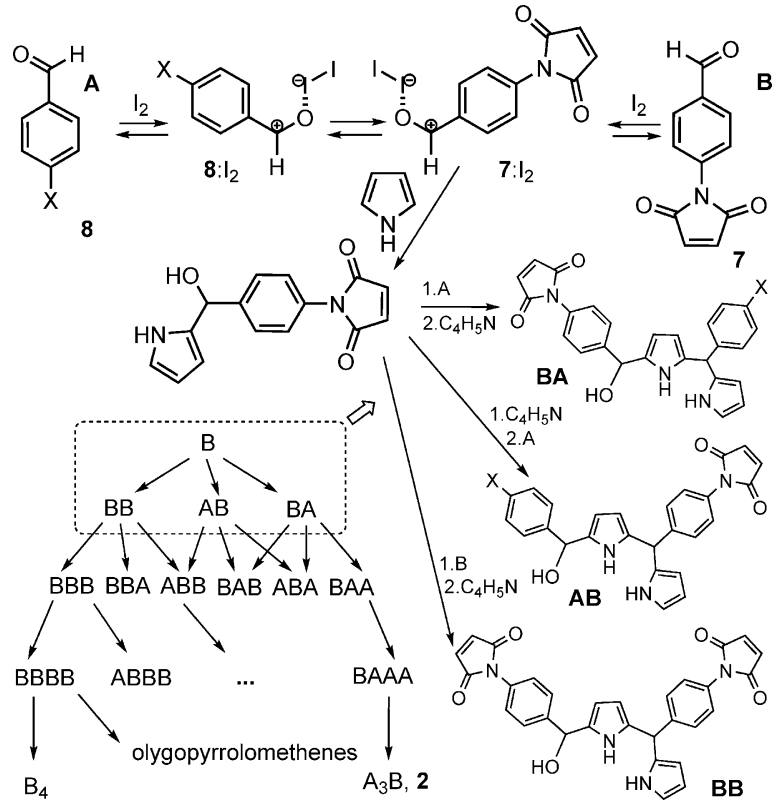

Scheme 3. $I_{2}$-activation of $A$ and $B$ aldehydes directing predominant inclusion of either the $A$ or $B$ component into the porphyrinogen.

reaction mixture. This can be clearly seen in Figure 1, which shows that the maximum $B_{4}$-porphyrin concentration was reached after about $2 \mathrm{~h}$ as compared to $2.5 \mathrm{~h}$ for $\mathrm{A}_{3} \mathrm{~B}$-porphyrin $\mathbf{2} \mathbf{b}$ in the reaction of aldehyde $\mathbf{8} \mathbf{b}$ with pyrrole. Porphyrinogen formation is known to be often reversible. Hence, along with the independent formation of $\mathrm{A}_{3} \mathrm{~B}$-porphyrin and other porphyrins, the obtained $B_{4}$-porphyrinogen reacts with aldehyde $\mathbf{8} \mathbf{b}$ or $\mathbf{8} \mathbf{d}$ leading to the whole set of $A_{x} B_{4-x}$ porphyrins, but these reactions proceed at lower rates than the formation of $\mathrm{B}_{4}$. On the contrary, the Lewis basicities of $\mathbf{8} \mathbf{a}$ and $\mathbf{8 c}$ are close to that of $\mathbf{7}$ and therefore in these cases aldehydes of both types, A and B, are activated to similar extents. This leads to a statistical distribution of products from the very beginning of the reaction and, as a result, the maximum yield point is reached earlier. This observation may be useful for the synthesis of other mixed porphyrins. Thus, the greater the difference in the Lewis basicities of the aldehydes used, the longer the optimal reaction time for the synthesis of a mixed porphyrin is likely to be, provided that a mild Lewis acid is employed as the catalyst.

Analysis of the ratio of the different porphyrins in the reaction mixture obtained by reacting pyrrole, aldehyde 7 , and one of $\mathbf{8} \mathbf{b}-\mathbf{d}$ showed that the stoichiometric ratio of 7:8 (1:3) resulted in a virtually statistical distribution of products (Table 2). Hence, no further improvement in the yield of the target porphyrins 2 was possible by varying the 7:8 ratio.

Next, porphyrins $\mathbf{2 a - c}$ were reacted with bis-aziridine 6 in refluxing benzene to give mono-adducts $5 \mathrm{a}-\mathrm{c}$ in $40-45 \%$ yield along with bis-adducts $9 \mathrm{a}-\mathrm{c}$ in $20-30 \%$ yield as by-products (Scheme 4, Table 3). As is typical for thermal reactions of 2,3dialkoxycarbonylaziridines with active dipolarophiles, ${ }^{[66,23]}$ the reaction proceeded stereoselectively through 1,3-electrocyclic ring-opening of the cis-aziridine ring to give the S-shaped 
Table 2. Distribution of porphyrins in the reaction mixture at the point of maximum yield of $A_{3} B$ porphyrin.

\begin{tabular}{|c|c|c|c|c|c|c|}
\hline & & $\mathrm{A}_{4}$ & $\mathrm{~A}_{3} \mathrm{~B}$ & $\mathrm{~A}_{2} \mathrm{~B}_{2}$ & $\mathrm{AB}_{3}$ & $\mathrm{~B}_{4}$ \\
\hline statistical distribution & & 31 & 42 & 21 & 5 & 0.5 \\
\hline ratio of porphyrins & $8 \mathbf{b}^{[a]}$ & 21 & 41 & 26 & 8 & 4 \\
\hline \multirow[t]{2}{*}{ according to HPLC } & $8 c^{[a]}$ & 18 & 40 & 30 & 9 & 3 \\
\hline & $8 d^{[b]}$ & 24 & 41 & 24 & 7 & 2 \\
\hline
\end{tabular}

[a] Chromatographic peaks were assigned on the basis of LC-MS data. [b] Chromatographic peaks were assigned based on the retention times and relative order of peaks in the reactions of aldehydes $\mathbf{8 b}$ and $\mathbf{8 c}$.

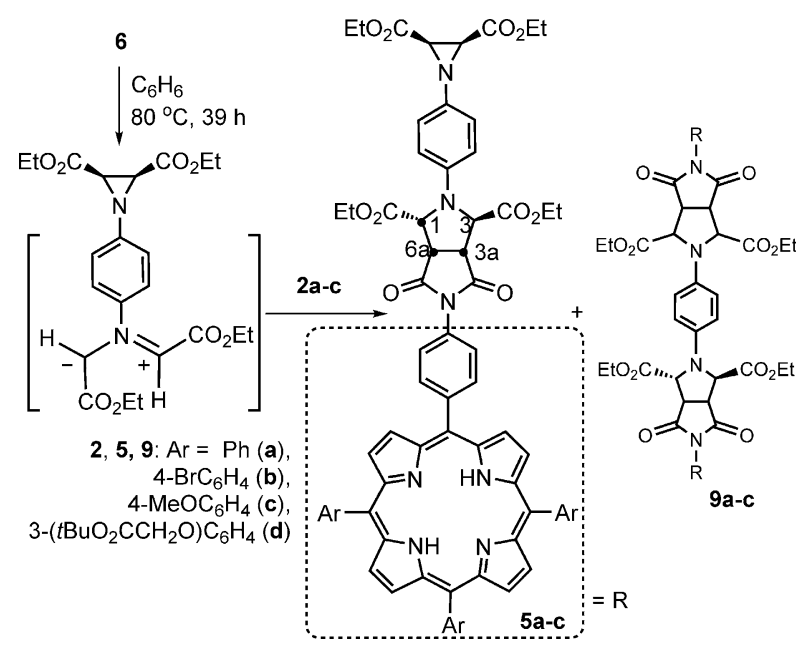

Scheme 4. Synthesis of porphyrin building blocks 5 a-c.

\begin{tabular}{|llll|}
\hline \multicolumn{3}{|c|}{ Table 3. Synthesis of porphyrin building blocks $\mathbf{5}$ a-c. } \\
& $\mathrm{Ar}$ & Yield of $\mathbf{5}[\%]^{[\mathrm{a}]}$ & Yield of $\mathbf{9}[\%]^{[a]}$ \\
\hline $\mathbf{5 a}$ & $\mathrm{Ph}$ & 41 & 24 \\
$\mathbf{5} \mathbf{b}$ & $4-\mathrm{BrC}_{6} \mathrm{H}_{4}$ & 43 & 28 \\
$\mathbf{5} \mathbf{C}$ & $4-\mathrm{MeOC}_{6} \mathrm{H}_{4}$ & 44 & 23 \\
\hline
\end{tabular}

[a] Isolated yields.

azomethine ylide, followed by 1,3-dipolar cycloaddition of the latter across the activated maleimide carbon-carbon double bond in porphyrins 2, yielding exclusively the trans adduct with the cis configuration of the remaining aziridine ring being retained. The configuration of the latter in mono-adducts $\mathbf{5}$ was evident from the spin-spin coupling constant of the aziridine proton signals at $\delta=2.5-2.6 \mathrm{ppm}$ in the ${ }^{1} \mathrm{H}$ NMR spectra of $5 \mathrm{a}-\mathrm{c}$, which showed a value of $6.5 \mathrm{~Hz}$, typical for cis-aziridines ${ }^{[23 b, c, 24]}$ (cf. 0-3 Hz for trans-aziridines). ${ }^{[23 b, c, 24,25]}$ Taking into account the non-equivalence of the aziridine protons (two doublets in the ${ }^{1} \mathrm{H}$ NMR spectrum) and the impossibility of changing the configuration of the succinimide fragment in the absence of a strong base, the configuration of the pyrrolo[3,4c]pyrrole fragment has to be $r-1, t-3, c-3 a, c-6 a$, as shown in Scheme 4. Bis-adducts 9 were obtained as mixtures of two diastereomers. As these compounds represent by-products, they were only characterized by ${ }^{1} \mathrm{H}$ NMR spectroscopy, with the data obtained being consistent with the proposed structures.

Finally, the obtained porphyrin building blocks could be submitted to the reaction with fullerene to give, after oxidation, the target compounds. To this end, porphyrins $\mathbf{5}$ a-c were reacted with excess fullerene $C_{60}$ in refluxing chlorobenzene. The formation of the cycloadduct was confirmed by mass spectrometry in the case of porphyrin $\mathbf{5} \mathbf{c}$, and in the reaction of porphyrin $\mathbf{2} \mathbf{d}$ with bis-aziridine $\mathbf{6}$, in which case the intermediate product was isolated and characterized by HRMS. The observed mass and isotope distribution of the molecular ion were in good agreement with the calculated values (1968.4703 vs. 1968.4713 and 2269.6294 vs. $2269.6319 \mathrm{Da}$, respectively; see the Supporting Information). In scaled-up experiments, the intermediate cycloadducts were dehydrogenated with 2,3-dichloro-5,6-dicyano-1,4-benzoquinone (DDQ) in refluxing chlorobenzene without isolation to give the desired porphyrinfullerenes $\mathbf{1} \mathbf{a}-\mathbf{c}$ in $20-35 \%$ yield in a one-pot procedure (Scheme 5).

$$
\text { 5a-c } \frac{\text { 1) } \mathrm{C}_{60}, 100^{\circ} \mathrm{C}, \mathrm{PhCl}}{2) \mathrm{DDQ}, \mathrm{mw}, 130^{\circ} \mathrm{C}} \text { 1a-c }
$$

Scheme 5. Synthesis of the target porphyrin-fullerenes $\mathbf{1}$ a-c.

Dyad $1 \mathbf{d}$ was obtained in $10 \%$ yield by reacting porphyrin $2 \mathbf{d}$ and aziridine-fullerene $4^{[23 \mathrm{~b}]}$ in o-dichlorobenzene at $90^{\circ} \mathrm{C}$ followed by oxidation with DDQ (microwave activation, $75 \mathrm{~W}$, $\left.127^{\circ} \mathrm{C}\right)$.

HRMS data were consistent with the elemental compositions of $\mathbf{1} \mathbf{b}-\mathbf{d}$. The ${ }^{1} \mathrm{H}$ NMR spectrum of $\mathbf{1} \mathbf{a}$ was identical to the literature data. ${ }^{[6 \mathrm{~b}]}$ The ${ }^{1} \mathrm{H}$ NMR spectra of $\mathbf{1} \mathbf{b}$ - $\mathbf{d}$ featured characteristic signals of $\mathrm{NH}$ porphyrin protons at $\delta=-2.74$ to $-2.84 \mathrm{ppm}$, porphyrin $\beta$-pyrrolic protons at $\delta=8.87-9.01 \mathrm{ppm}$, and fulleropyrrolidine protons at $\delta=6.57-6.58 \mathrm{ppm}$ (characteristic of trans-fulleropyrrolidine ${ }^{[23 b, c]}$ ), along with the signals of ethoxy groups ( $\delta=4.31-4.43$ and $1.24-1.47 \mathrm{ppm}$ ) and 1,4-disubstituted benzene rings (six signals). The ${ }^{13} \mathrm{C}$ NMR spectra of $\mathbf{1} \mathbf{b}, \mathbf{c}$ featured characteristic signals of $\mathrm{sp}^{3}$ pyrrolofullerene carbons at $\delta \approx 75$ and $71 \mathrm{ppm}$. According to the HSQC spectrum of $\mathbf{1} \mathbf{b}$ (see the Supporting Information), the signal at $\delta=$ $75 \mathrm{ppm}$ corresponds to a pyrrolidine- $\mathrm{CH}$ carbon $(6.54 \times 74.7$ cross-peak $\left({ }^{1} \mathrm{H} \times{ }^{13} \mathrm{C}\right.$ chemical shifts)), which suggests that the remaining signal at $\delta \approx 71 \mathrm{ppm}$ corresponds to the quaternary carbon atom of the pyrrolidine ring. This was confirmed by the HMBC spectrum of $\mathbf{1} \mathbf{b}$ (see the Supporting Information), in which cross-peaks of the pyrrolidine- $\mathrm{CH}$ proton with both the pyrrolidine- $\mathrm{CH}$ carbon $\left({ }^{3} \mathrm{~J}_{\mathrm{CH}}\right.$ or $\left.{ }^{4} \mathrm{~J}_{\mathrm{CH}}\right)$ and quaternary pyrrolidine carbons $\left({ }^{2} J_{\mathrm{CH}}\right.$ or $\left.{ }^{3} J_{\mathrm{CH}}\right)$ were observed. In addition, spin-spin coupling $\left({ }^{3} J_{\mathrm{CH}}\right)$ of the pyrrolidine- $\mathrm{CH}$ proton with the closest $\mathrm{sp}^{2}$ carbons of the fullerene cage was evident from the HMBC spectrum of $\mathbf{1} \mathbf{b}$, according to two cross-peaks at $6.54 \times 152.9$ and $6.54 \times 149.9 \mathrm{ppm}$, the former being fourfold more intense, which means that the signal at $\delta=152.9 \mathrm{ppm}$ corresponds to the cis carbon (dihedral angle $\mathbf{H C C C}^{\text {sp2 }}$ close to $0^{\circ}$ ), whereas the signal at $\delta=149.9 \mathrm{ppm}$ corresponds to the trans carbon 
(dihedral angle $\mathrm{HCCC}^{\mathrm{sp} 2}$ close to $90^{\circ}$ ). Spin-spin coupling was also observed between the pyrrolidine- $\mathrm{CH}$ proton and the carbonyl carbon of the closest ester group $\left({ }^{2} J_{\mathrm{CH}}\right)$ as a cross peak at $6.54 \times 169.9 \mathrm{ppm}$. From here, the methylene protons of the ethyl groups closest to the $C_{60}$ can be discerned through a cross-peak with the ester carbonyl carbon at $4.32 \times$ $169.9 \mathrm{ppm}$. The methylene protons from the remaining pair of equivalent ethyl groups attached to the central pyrrolo[3,4c]pyrrolic core thus give rise to the signal at $\delta=4.39 \mathrm{ppm}$. All methylene carbons have accidentally the same signal at $\delta=$ $62.2 \mathrm{ppm}$, according to HMQS of $\mathbf{1} \mathbf{b}$. However, the methyl carbons of the different ethyl groups have distinct signals at $\delta=$ 14.3 and $14.2 \mathrm{ppm}$. The HMBC spectrum of $\mathbf{1} \mathbf{b}$ allows their assignment: that at $\delta=14.3$ corresponds to the methyl carbons closest to $\mathrm{C}_{60}$ (cross-peak at $4.32 \times 14.3 \mathrm{ppm}$ ) and that at $\delta=$ 14.2 corresponds to the methyl carbons closest to the pyrrolo[3,4-c]pyrrolic core $(4.39 \times 14.2 \mathrm{ppm})$. The signal of the ester carbonyl carbon in these ethoxycarbonyl groups appears out of the usual range at $\delta=157.9 \mathrm{ppm}$, which can be discerned from a cross-peak with the corresponding methylene proton signal $\left(4.39 \times 157.9 \mathrm{ppm},{ }^{3} \mathrm{~J}_{\mathrm{CH}}\right)$. As these protons show only two cross-peaks, one of them being with the methyl carbons, the assignment made ( $\delta=157.9 \mathrm{ppm}, \mathrm{C}=\mathrm{O}$ ) seems to be the only one possible. As there are only three signals in the ester carbonyl region of the ${ }^{13} \mathrm{C}$ NMR spectrum of $\mathbf{1} \mathbf{b}(\delta=169.9,161.2$, and $157.9 \mathrm{ppm}$ ), the imide carbonyl must give rise to the signal at $\delta=161.2 \mathrm{ppm}$. Analogous signals $(\delta=170.0,161.3$, and $157.9 \mathrm{ppm}$ for $\mathrm{C}=\mathrm{O}$ and $\delta=62.2,14.3$, and $14.2 \mathrm{ppm}$ for EtO) were observed in ${ }^{13} \mathrm{C}$ NMR spectrum of $1 \mathrm{c}$. Another characteristic feature of the ${ }^{13} \mathrm{C}$ NMR spectra of $\mathbf{1} \mathbf{b}, \mathbf{c}$ is a broad singlet at $\delta \approx 131 \mathrm{ppm}$, which corresponds to the $\beta$-pyrrolic carbons of the porphyrin core, and is broadened due to exchange of the $\mathrm{NH}$ protons. The meso-porphyrin carbons in $\mathbf{1} \mathbf{b}, \mathbf{c}$ give rise to signals at $\delta \approx 119 \mathrm{ppm}$ in the ${ }^{13} \mathrm{C}$ NMR spectra. This follows from analysis of the $\mathrm{Br}_{-} \mathrm{C}_{6} \mathrm{H}_{4^{-}}$region in the $\mathrm{HMBC}$ and HSQC spectra of $\mathbf{1} \mathbf{b}$. The ${ }^{1} \mathrm{H}$ NMR data allow assignment of the multiplets at $\delta=7.9$ and $8.1 \mathrm{ppm}$ to the protons of $p$-Br-substituted benzene rings $C, D$ (Scheme 6 ) on the basis of their intensity ( $6 \mathrm{H}$ each) and evident "roof effect". This gives chemical shifts of $\delta=130.1$ and $135.9 \mathrm{ppm}$ for the respective carbon atoms to which they are attached (HSQC). The HMBC spectrum features four cross-peaks for each of the above protons (with a total of five different carbon atoms, including those giving

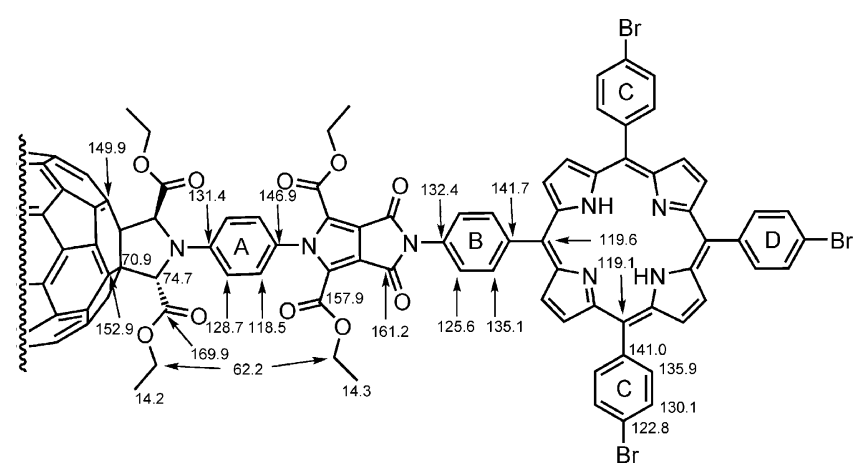

Scheme 6. Assignment of signals in the ${ }^{13} \mathrm{C}$ NMR spectrum of $\mathbf{1} \mathbf{b}$. signals at $\delta=130.1$ and $135.9 \mathrm{ppm}$ ), the most intense being that with the ipso carbons (dihedral angle HCCC Hpso close to $\left.180^{\circ}\right)$ at $8.1 \times 122.8$ and $7.9 \times 141.0 \mathrm{ppm}$. The remaining signal at $\delta=119.1 \mathrm{ppm}(8.1 \times 119.1 \mathrm{ppm})$ thus corresponds to a meso carbon of the porphyrin core, the other signals being assigned as follows: $\delta=141.0$ ( $\mathrm{C}^{\text {ipso }}$ ) (with respect to porphyrin), 135.9 $\left(\mathrm{C}^{\text {ortho }}\right), 130.1\left(\mathrm{C}^{\text {meta }}\right)$, and $122.8 \mathrm{ppm}\left(\mathrm{C}^{\text {para }}=\mathrm{C}^{\text {ipso }}-\mathrm{Br}\right)$. Analogously, we assigned the signals for benzene ring $B$ as follows (Scheme 6): $\delta=119.6$ (meso-porphyrin carbon), $141.7\left(C^{i p s o}\right)$, $135.1\left(\mathrm{C}^{\text {ortho }}\right), 125.6\left(\mathrm{C}^{\text {meta }}\right)$, and $132.4 \mathrm{ppm}\left(\mathrm{C}^{\text {para }}=\mathrm{C}^{\text {ipso }}-\mathrm{N}\right)$. Finally, according to the HSQC and HMBC data, the signals of benzene ring $\mathrm{A}$ (Scheme 6) in $\mathbf{1} \mathbf{b}$ appear at $\delta=146.9$ and $131.4 \mathrm{ppm}$ for the $\mathrm{N}-\mathrm{C}^{\text {ipso }}$ carbon atoms and $\delta=128.7$ and $118.5 \mathrm{ppm}$ for the $\mathrm{CH}$ carbon atoms. Presumably, the carbon atoms giving the signals at $\delta=131.4$ and $128.7 \mathrm{ppm}$ are those closest to $C_{60}$. The assignments of the ${ }^{13} \mathrm{C}$ NMR signals for $1 \mathbf{b}$ are summarized in Scheme 6 . The ${ }^{13} \mathrm{C}$ NMR spectrum of $1 \mathrm{c}$, in addition to signals analogous to those described above for the aromatic system of $\mathbf{1} \mathbf{b}\left(\delta=153.0,150.1\left(C^{\text {sp2 }} C_{60}\right), 146.9,141.7\right.$, $135.2,132.1,131.4,128.6,125.6,120.1,118.8$, and $118.5 \mathrm{ppm})$, features signals due to the 4-MeO-substituted benzene ring $(\delta=159.4,144.4,120.3$, and $112.4 \mathrm{ppm})$ and MeO group $(\delta=$ $55.7 \mathrm{ppm})$.

\section{Computational study}

A charge-separated state in a porphyrin-fullerene dyad represents an electronically excited state of the molecule formally obtained by excitation of an electron from an occupied molecular orbital located on the porphyrin moiety to a vacant molecular orbital located on the fullerene core. Hence, it can be characterized by analyzing the electronic states of a given molecule. To date, a number of literature reports have been devoted to quantum chemical analysis of porphyrin-fullerene ensembles, with TD DFT being shown to be a method giving reasonable results when applied to the analysis of the excited states of these systems. ${ }^{[26]}$ Consequently, to determine the factors stabilizing and destabilizing the charge-separated state, we performed TD DFT calculations on a series of axially symmetric porphyrin-fullerenes $\mathbf{1}$ 'a-d (Scheme 7), bearing various substituents on the porphyrin core, close analogues of the synthesized dyads $\mathbf{1} \mathbf{a}-\mathbf{d}$. The structures of model compounds $\mathbf{1}^{\prime} \mathbf{a}-\mathbf{d}$ are simplified compared to the synthesized compounds $1 \mathrm{a}-\mathbf{d}$ : the ethyl group is changed to a methyl group in the alkoxycarbonyl substituent in each case. Moreover, the complex alkoxy substituent at the benzene rings in $\mathbf{1} \mathbf{d}$ is replaced by

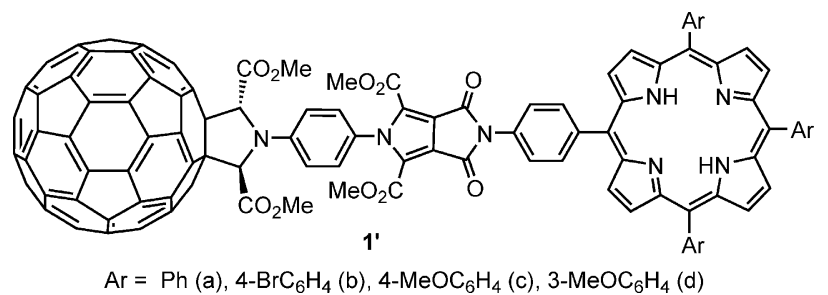

Scheme 7. Model compounds $\mathbf{1}^{\prime} \mathbf{a}-\mathbf{d}$ for computational study. 
a methoxy substituent in $\mathbf{1}^{\prime} \mathbf{d}$. These changes do not significantly affect the electronic structure of the molecules, but allow the application of a more profound level of theory for the key porphyrin-fullerene fragment. The geometries of all compounds were optimized at the DFT B3LYP 6-31G(d) level of theory and frequency analyses were performed to prove that the obtained structures corresponded to minima on the potential energy surfaces. Detailed descriptions of the optimized structures are given in the Supporting Information.

According to the performed TD DFT calculations, the studied states can be classified into five groups, depending on the localization of the orbitals involved (Figure 2): singlet porphyrin
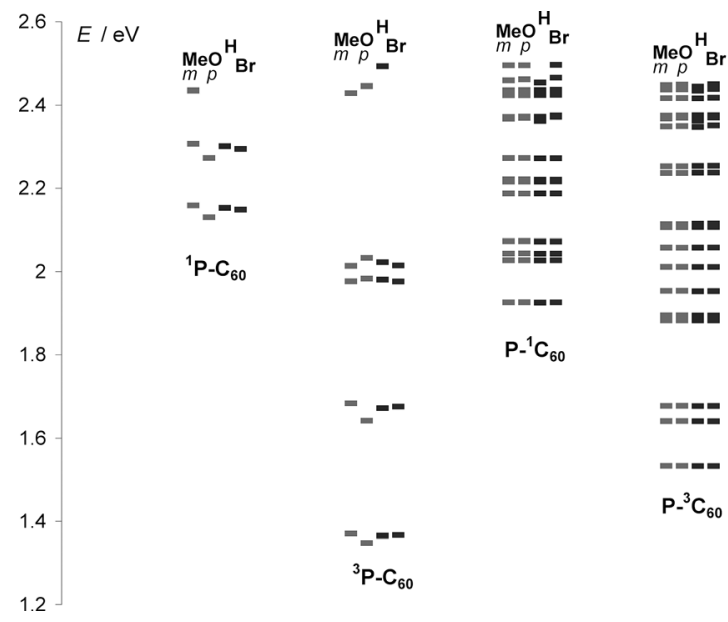

$\underset{m p}{\mathrm{MeO}}{ }_{\mathrm{Br}}^{\mathrm{H}}$

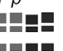

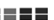

$-\overline{-}$

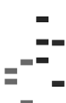

$=$

-

$=-$

$=$

cs

Figure 2. Diagram of the electronically excited states distribution in compounds $1^{\prime}$. Only the excited states within a $2.5 \mathrm{eV}$ range (50-54 lowest states) are given. This range covers all possible transitions in the Q-bands region $(\lambda>495 \mathrm{~nm})$. For tabulated values of the energies of the excited states, see the Supporting Information (Table SI3).

${ }^{1} \mathrm{P}-\mathrm{C}_{60}(E \geq 2.13 \mathrm{eV})$, triplet porphyrin ${ }^{3} \mathrm{P}-\mathrm{C}_{60}(E \geq 1.35 \mathrm{eV})$, singlet fullerene $\mathrm{P}^{-}{ }^{1} \mathrm{C}_{60}(E \geq 1.93 \mathrm{eV})$, triplet fullerene $\mathrm{P}^{3}{ }^{3} \mathrm{C}_{60}(E \geq$ $1.53 \mathrm{eV}$ ), and charge-separated (CS) states (from $E \geq 1.41 \mathrm{eV}$ for $\mathbf{1}^{\prime}$ a to $E \geq 1.80 \mathrm{eV}$ for $\mathbf{1}^{\prime} \mathbf{b}$ ). The latter can exist in a singlet or a triplet state. However, no energy difference was observed for the singlet and triplet states of a given charge-transfer state in dyads $\mathbf{1}^{\prime}$. The above energy values for the lowestenergy state of each kind are in reasonable agreement with previous reports on compounds bearing similar structural motifs $\left(2.13,^{[26 \mathrm{~d}]} 1.40,^{[26 \mathrm{e}]} 1.88^{[26 \mathrm{~d}]} 1.53^{[16 \mathrm{a}]} 2.05^{[26 \mathrm{a}]}\right.$ and $\left.1.46 \mathrm{eV}^{[26 c]}\right)$.

As the UV/Vis spectra of porphyrin-fullerenes 1 consist mostly of bands corresponding to transitions from the ground state to the singlet states centered on the porphyrin, the energies of the $\left({ }^{1} \mathrm{P}-\mathrm{C}_{60}\right)_{n}$ states in $\mathbf{1}^{\prime}$ can be used to independently evaluate the accuracy of the computational method. The results are summarized in Table 4. Only bands corresponding to transitions between electronic states with the same vibrational mode were analyzed. As one can see from these data, the energies of the main electronic transitions and their relative probabilities were qualitatively reproduced, which validates application of this computational method for comparison of a series of structurally similar compounds.
Table 4. Calculated and experimental UV/Vis data for compounds 1 and $1^{\prime}$. ${ }^{\text {a] }}$

\begin{tabular}{|c|c|c|c|c|c|c|}
\hline & \multirow[t]{2}{*}{ State } & \multicolumn{2}{|c|}{ Wavelength [nm] } & \multirow{2}{*}{$\begin{array}{l}\Delta \lambda \\
{[\mathrm{nm}]}\end{array}$} & \multirow[t]{2}{*}{$\log \varepsilon$} & \multirow{2}{*}{$\begin{array}{l}\text { Calcd } \\
\text { oscillator } \\
\text { strength }\end{array}$} \\
\hline & & $1^{[a]}$ & $1^{\prime[a]}$ & & & \\
\hline $1^{\prime} \mathrm{a} / 1 \mathrm{a}$ & $\left({ }^{1} \mathrm{P}-\mathrm{C}_{60}\right)_{1}$ & $645^{[b, c]}$ & 576 & 69 & $4.09^{[b, c]}$ & 0.0258 \\
\hline $1^{\prime} a / 1 a$ & $\left({ }^{1} \mathrm{P}-\mathrm{C}_{60}\right)_{2}$ & $549^{[b, c]}$ & 539 & 10 & $4.32^{[b, c]}$ & 0.0499 \\
\hline $1^{\prime} \mathrm{a} / 1 \mathrm{a}$ & $\left({ }^{1} \mathrm{P}-\mathrm{C}_{60}\right)_{3}$ & $417^{[b, c]}$ & 393 & 24 & $6.01^{[b, c]}$ & 1.0076 \\
\hline $1^{\prime} b / 1 b$ & $\left({ }^{1} \mathrm{P}-\mathrm{C}_{60}\right)_{1}$ & 645 & 577 & 68 & 3.48 & 0.0290 \\
\hline $1^{\prime} b / 1 b$ & $\left({ }^{1} \mathrm{P}-\mathrm{C}_{60}\right)_{2}$ & 550 & 540 & 10 & 3.82 & 0.0607 \\
\hline $1^{\prime} b / 1 b$ & $\left({ }^{1} \mathrm{P}-\mathrm{C}_{60}\right)_{3}$ & 420 & 394,382 & 26,38 & 5.56 & $1.0256,1.5952$ \\
\hline $1^{\prime} \mathrm{c} / 1 \mathrm{c}$ & $\left({ }^{1} \mathrm{P}-\mathrm{C}_{60}\right)_{1}$ & 645 & 582 & 63 & 3.92 & 0.0400 \\
\hline $1^{\prime} \mathrm{c} / 1 \mathrm{c}$ & $\left({ }^{1} \mathrm{P}-\mathrm{C}_{60}\right)_{2}$ & 551 & 546 & 5 & 4.22 & $0.0246,0.0538$ \\
\hline $1^{\prime} \mathrm{c} / 1 \mathrm{c}$ & $\left({ }^{1} \mathrm{P}-\mathrm{C}_{60}\right)_{3}$ & 420 & 396,388 & 24,32 & 5.85 & $1.2034,1.4936$ \\
\hline
\end{tabular}

[a] 1': calculated data, vacuum; 1: experimental data, 1,2-dichloroethane. [b] $\mathrm{CH}_{2} \mathrm{Cl}_{2}$. [c] Ref. [6b].

It was found that the substituents on the porphyrin core had virtually no effect on the states obtained by the transition of electrons between fullerene-centered MOs, which was to be expected, and only minor effects on the states obtained by the transition of electrons between porphyrin-centered MOs ( $\Delta E$ up to $0.02 \mathrm{eV}$; Figure 2). On the contrary, the charge-transfer states were seen to be strongly affected by the substituent, with $\Delta E$ being up to $0.4 \mathrm{eV}$ ( $\mathbf{1}^{\prime} \mathbf{b}$ vs. $\mathbf{1}^{\prime} \mathbf{c}$; Figure 2). It was found that electron-withdrawing substituents on the phenyl rings attached at the meso positions of the porphyrin, such as $p$ bromo, strongly increased the energies of the CS states, whereas electron-donating substituents, such as $p$-methoxy, strongly decreased the energy of the CS states. Thus, the energy of the lowest CS state of $1 \mathrm{a}(\mathrm{H})$ is $0.24 \mathrm{eV}$ lower than that of $\mathbf{1} \mathbf{b}(p-\mathrm{Br})$ and $0.16 \mathrm{eV}$ higher than the corresponding state of 1 c $(p-M e O)$. The most logical explanation implies stabilization of the positive charge on the porphyrin fragment by an electron-donor group and its destabilization by an electronacceptor group. It is noteworthy that the $m-\mathrm{MeO}$ substituent in $\mathbf{1}^{\prime} \mathbf{d}$ also stabilizes the CS state in comparison with $\mathbf{1}^{\prime} \mathbf{a}$, albeit to a lesser extent than the $p-\mathrm{MeO}$ group. Combined with the observation that in all of the compounds $\mathbf{1}^{\prime}$ the phenyl rings are almost perpendicular to the porphyrin plane, this rules out a simple explanation based on classical concepts of mesomeric and inductive effects of substituents. Instead, a through-space field effect seems to be involved: the energy increase upon formation of a positive charge on the porphyrin fragment can be attenuated by polarization of the adjacent phenyl rings so that the resulting local dipole moments compensate the developing global dipole moment upon CS state formation. Hence, when an electron-donating substituent, such as an $\mathrm{MeO}$ group, is attached to the phenyl ring, the polarizability of the ring increases, whereas an electron-withdrawing substituent, such as bromo, reduces the polarizability of the phenyl ring and prevents its participation in stabilization of the positive charge on the porphyrin fragment.

Interestingly, introduction of a $p$-methoxy substituent on the phenyl ring in the meso position of the porphyrin moiety resulted in significant mixing of different states, implying better interaction of the different $\pi$-systems that contain $1^{\prime}$ c com- 
pared to $\mathbf{1}^{\prime} \mathbf{a}, \mathbf{b}$. Thus, the $\left(\mathrm{P}^{-1} \mathrm{C}_{60}\right)_{8}$ state in $\mathbf{1}^{\prime} \mathbf{a}$ and $\mathbf{1}^{\prime} \mathbf{b}(2.2718$ and $2.2721 \mathrm{eV}$, respectively) corresponds to the transitions from the HOMO-6 (1'a)/HOMO-5 (1' b) and HOMO-4 (1' $\mathbf{a}, \mathbf{b})$ to the LUMO+2 $\left(\mathbf{1}^{\prime} \mathbf{a}, \mathbf{b}\right)$, all of them being localized almost entirely on the $\mathrm{C}_{60}$ core. Unlike in these compounds, there are two extremely close states for $\mathbf{1}^{\prime} \mathrm{c}$ at 2.2727 and $2.2728 \mathrm{eV}$, corresponding to transitions between MOs localized on the fullerene (HOMO-8, HOMO-7, HOMO-6 to LUMO+1, both states) as well as between MOs localized on the porphyrin (HOMO-1, $\mathrm{HOMO}$ to LUMO+4, LUMO+5 for the transition at $2.2727 \mathrm{eV}$ and also to LUMO+6 for the transition at $2.2728 \mathrm{eV})$. This is obviously the result of mixing of the $\left({ }^{1} \mathrm{P}-\mathrm{C}_{60}\right)_{2}$ and $\left(\mathrm{P}^{1} \mathrm{C}_{60}\right)_{8}$ states in $\mathbf{1}^{\prime} \mathrm{C}$ due to accidental proximity of their energies. In fact, the state at $2.2727 \mathrm{eV}$ has about $68 \%\left(\mathrm{P}^{-} \mathrm{C}_{60}\right)$ character and $26 \%\left({ }^{1} \mathrm{P}-\mathrm{C}_{60}\right)$ character, while the state at $2.2728 \mathrm{eV}$ has about $70 \%\left({ }^{1} \mathrm{P}-\mathrm{C}_{60}\right)$ character and $28 \%\left(\mathrm{P}^{1} \mathrm{C}_{60}\right)$ character (Figure 3 ). It should also be mentioned that in this case the

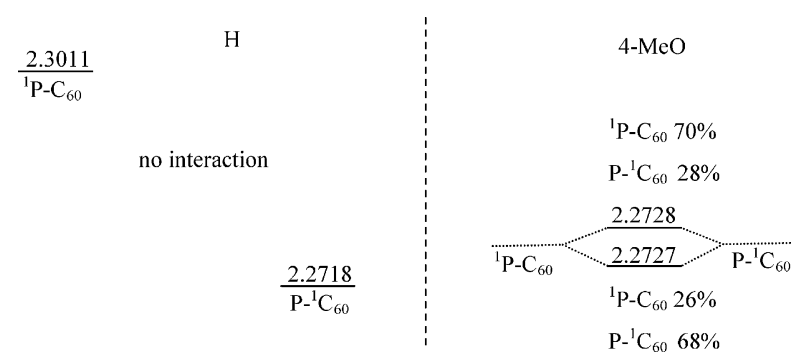

Figure 3. Interaction of $\left({ }^{1} \mathrm{P}-\mathrm{C}_{60}\right)_{2}$ and $\left(\mathrm{P}-{ }^{1} \mathrm{C}_{60}\right)_{8}$ in $\mathbf{1}^{\prime} \mathbf{c}$.

corresponding MOs localized on the fullerene also have significant coefficients on the adjacent pyrrolidine and phenyl rings (HOMO-8 and HOMO-7), and the MOs localized on the porphyrin "spread out" towards the pyrrolo[3,4-c]pyrrole linker (LUMO+4, LUMO+6).

Another interesting observation for $\mathbf{1}^{\prime} \mathbf{c}$ concerns the states at 2.3658 and $2.3608 \mathrm{eV}$ (not presented in Figure 2). These states are also CS states, as they are connected with the transition of an electron from the orbital centered on the porphyrin (HOMO) to the orbital centered on the pyrrolo[3,4-c]pyrrole linker (LUMO+3) (Figure 4), these being singlet and triplet states, respectively. Unlike the CS states with charge localization on the porphyrin and fullerene moieties, for which no difference in energy was observed, these two states differ by $0.005 \mathrm{eV}$, implying that it is spatial separation of two electrons with the same spin on the poles of the $C_{60}$ sphere that equalizes the energies of the triplet and singlet CS states for the ${ }^{+}\left[\mathrm{P}-\mathrm{C}_{60}\right]^{-}$state. However, the CS state with involvement of the pyrrolo[3,4-c]pyrrole linker is significantly higher in energy than the fullerene-based $\mathrm{CS}$, and so its formation seems improbable.

\section{Photophysics and electrochemistry}

All three porphyrin-fullerenes $\mathbf{1}$ a-c exhibit similar UV/Vis spectra in solution, featuring typical free-base porphyrin spectra (Figure 5), implying an absence of intramolecular electronic in-
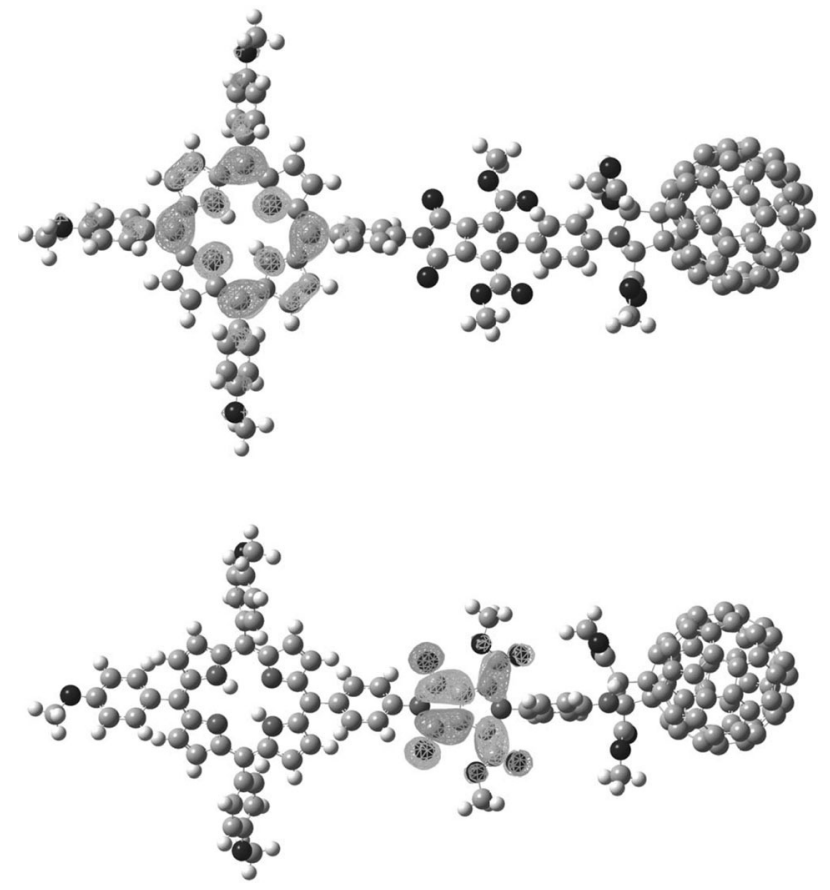

Figure 4. HOMO (top) and LUMO+3 (bottom) MOs in 1' c.

teraction of the chromophores in the ground state. Interestingly, a strong charge-transfer band was observed for a dry film of $1 \mathrm{a}$ on a transparent substrate at around $860 \mathrm{~nm}$ (Figure 6). This band disappeared upon immersion of the plate into acetonitrile, in which $\mathbf{1} \mathbf{a}$ is insoluble. This observation can be rationalized by assuming the charge-transfer band to be due to an intermolecular donor-acceptor interaction: the solvent molecules penetrate into the film and separate the porphyrin and fullerene moieties of different molecules from one another, thus preventing close-contact electronic interaction of the chromophores.

According to transient spectroscopy studies, the following photophysical processes take place upon excitation of porphy-

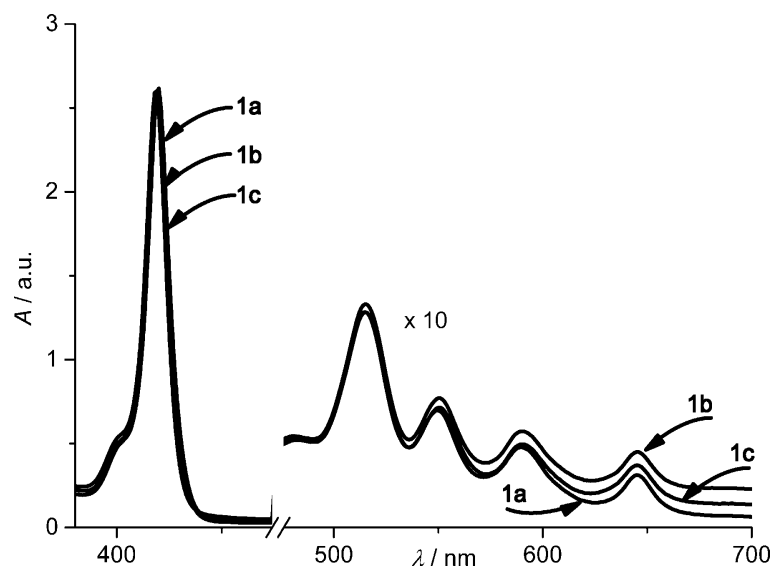

Figure 5. Absorption spectra of porphyrin-fullerenes $\mathbf{1}$ a-c in 1,2-dichloroethane. The concentration of samples was carefully adjusted to ensure matching of the absorption at the Soret band. 


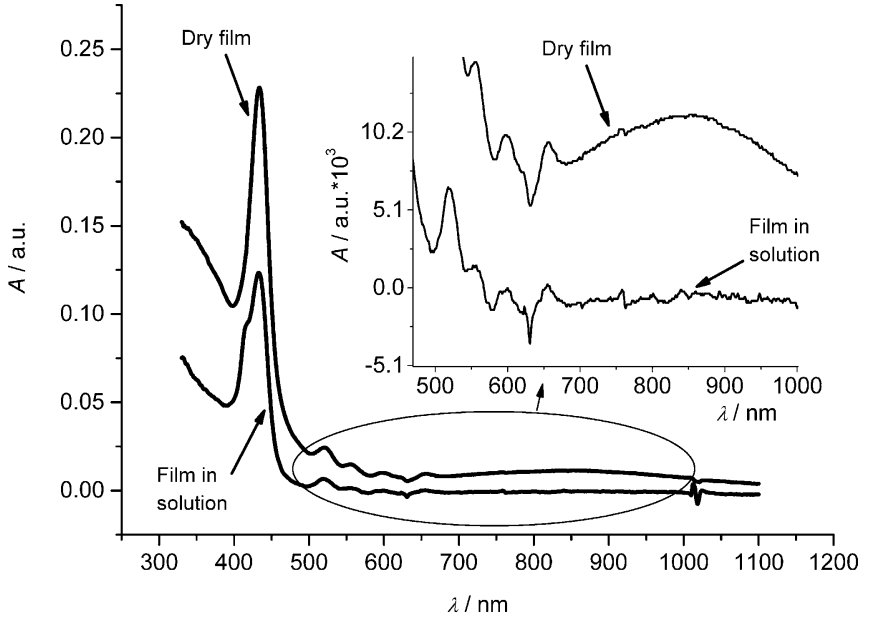

Figure 6. Absorption spectra of a thin film of $\mathbf{1}$ a on an ITO-coated glass plate in dry form and when immersed in $\mathrm{CH}_{3} \mathrm{CN}$.

rin-fullerenes $1 \mathbf{a}-\mathbf{c}$. Irradiation with $532 \mathrm{~nm}$ laser pulses excites $1 \mathrm{a}-\mathrm{c}$ to a short-lived first singlet state corresponding to the $650 \mathrm{~nm}$ band in the fluorescence spectrum. The lifetime of this state amounts to about 2 ns for $\mathbf{1} \mathbf{b}, \mathbf{c}$ and about $7 \mathrm{~ns}$ for $\mathbf{1} \mathbf{a}$, with the fluorescence quantum yields being $0.66,0.54$, and $2.6 \%$, respectively (Table 5, see also Figure SI3 in the Support-

Table 5. Excited-state lifetimes of $1 \mathrm{a}-\mathrm{c}$ and $10 \mathrm{a}-\mathrm{c}$ in 1,2-dichloroethane.

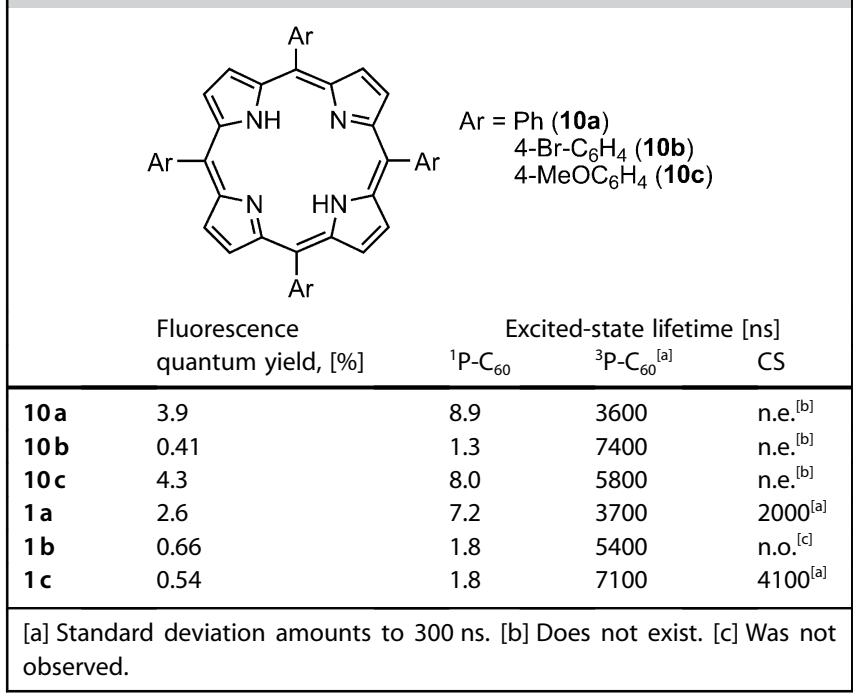

ing Information for illustrations). Two main channels for the decay of this state can be proposed: transition to the chargetransfer state and intersystem crossing leading to the first triplet state with the maximum spin density localized on the porphyrin $\left({ }^{3} \mathrm{P}-\mathrm{C}_{60}\right)_{1}$, proceeding either directly from $\left({ }^{1} \mathrm{P}-\mathrm{C}_{60}\right)_{1}$ or through a sequence of intermediate short-lived excited states.

Formation of the ${ }^{3} \mathrm{P}-\mathrm{C}_{60}$ state was evident for all compounds of the series from a transient absorption band at around $450 \mathrm{~nm}$, with the lifetime being about 3-7 $\mu$ s (Table 5, Figures 7 and 8). The triplet nature of this state was evident from the dependence of its lifetime on the presence of oxygen.

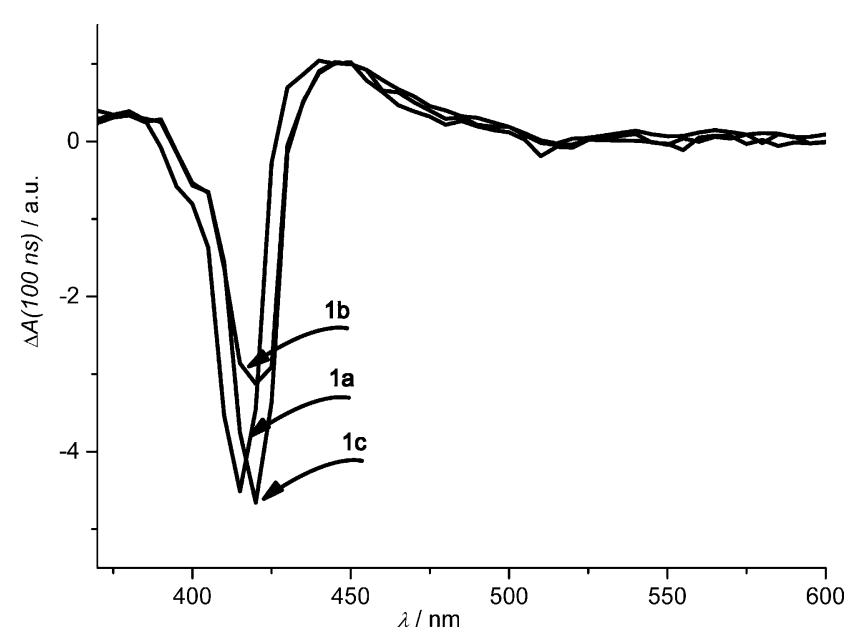

Figure 7. Scaled transient absorption $\triangle A$ spectra (UV/Vis range) of the porphyrin-fullerenes $1 \mathrm{a}-\mathrm{c}$ in deoxygenated 1,2-dichloroethane upon $532 \mathrm{~nm}$ excitation at a time delay of $100 \mathrm{~ns}$.

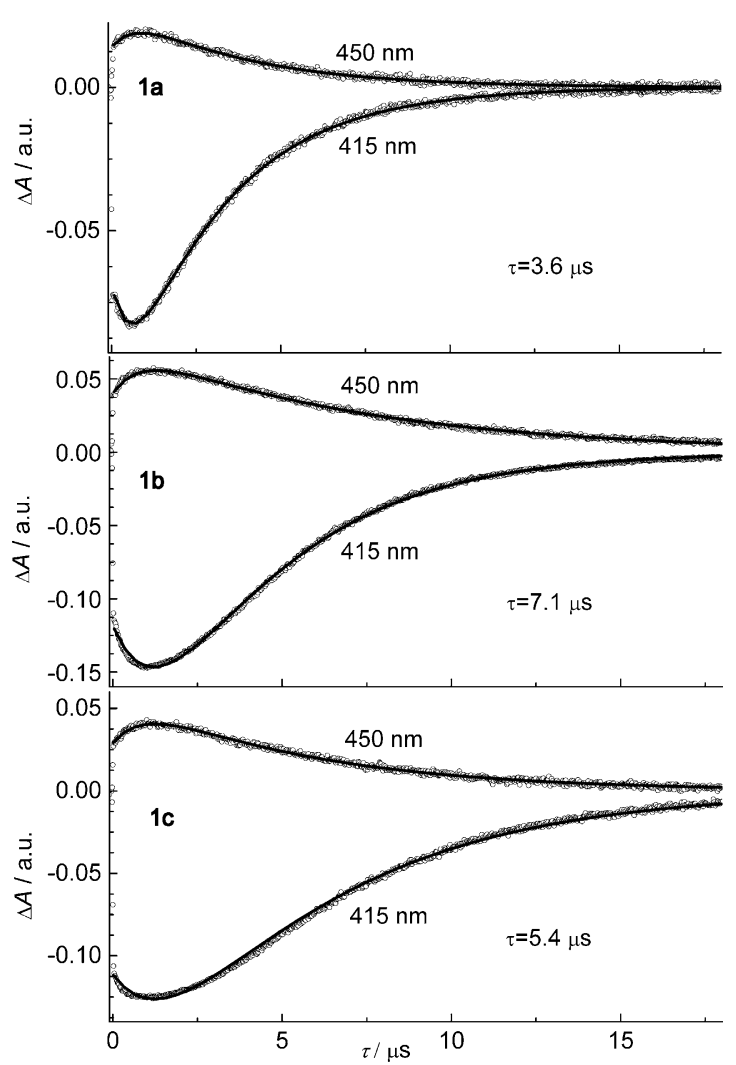

Figure 8. 415 and $450 \mathrm{~nm}$ transient absorption $\Delta A$ kinetic traces of the porphyrin-fullerenes $1 \mathbf{a}$-c in deoxygenated 1,2-dichloroethane upon $532 \mathrm{~nm}$ excitation. Two-exponential fits are shown as lines. Values of the decay time constant (lifetimes of the triplet state) $(\tau)$ are shown in the figure.

While the above value was obtained for deaerated solutions, the lifetime of this state in non-deaerated media was only around $1 \mu \mathrm{s}$ for all of the compounds. In addition, typical fluorescence of the singlet oxygen generated upon interaction of triplet oxygen with $\left({ }^{3} \mathrm{P}-\mathrm{C}_{60}\right)_{1}$ was observed at $1270 \mathrm{~nm}$ (see Figure SI4 in the Supporting Information for an illustration). 

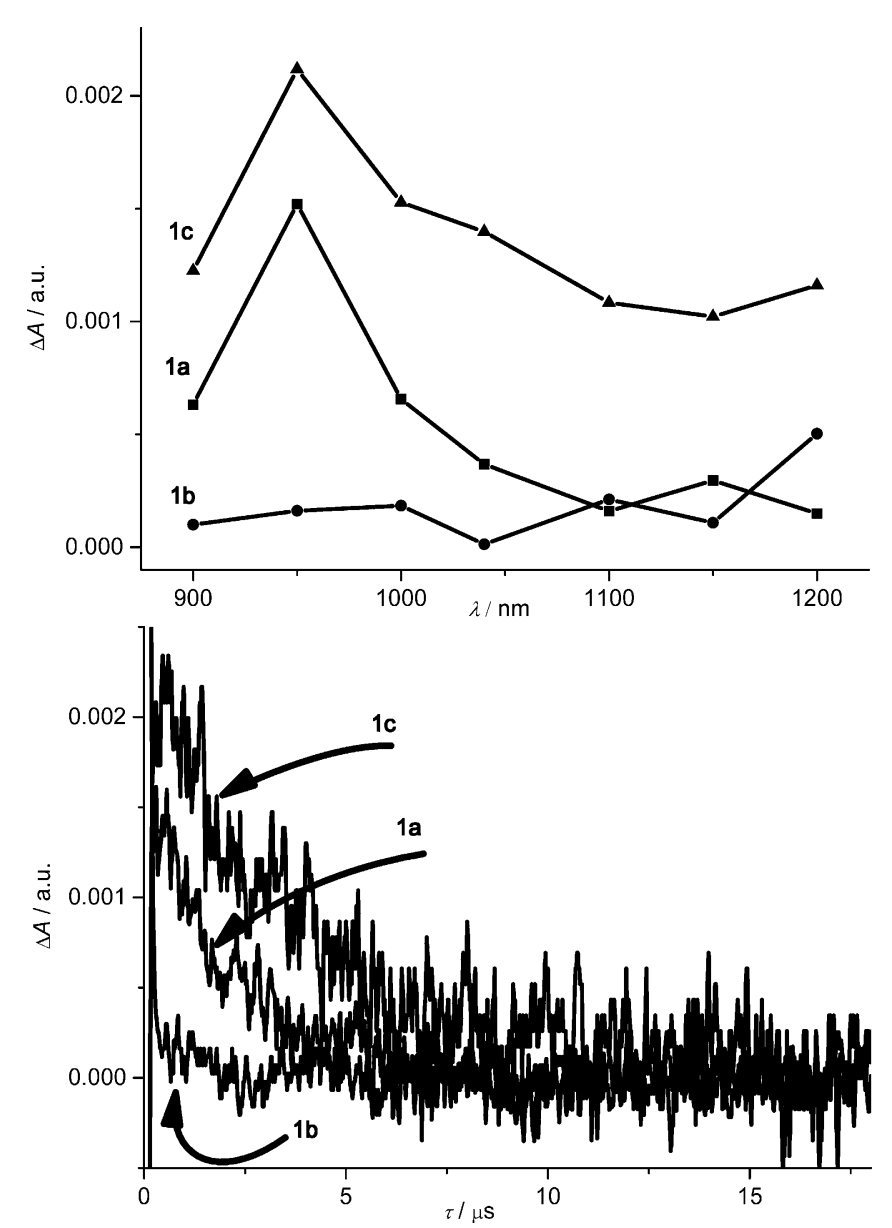

Figure 9. Transient absorption $500 \mathrm{~ns} \Delta A$ spectra (near-IR range, top) and $950 \mathrm{~nm}$ kinetic traces (bottom) of the porphyrin-fullerenes $1 \mathbf{a}-\mathrm{c}$ in deoxygenated 1,2-dichloroethane upon $532 \mathrm{~nm}$ excitation.

The CS state was not observed for $\mathbf{1} \mathbf{b}(\mathrm{Br})$, but could be clearly observed for $1 \mathbf{a}(\mathrm{H})$ and 1 c (4-MeO) as a weak transient absorption band at around $950 \mathrm{~nm}$, with lifetimes of around $2 \mu \mathrm{s}$ for $1 \mathrm{a}$ and $4 \mu \mathrm{s}$ for $1 \mathrm{c}$ (Figure 9 ). It should be noted that in oxygenated solution the lifetime of the CS state for $1 \mathrm{c}$ was reduced to $1 \mu \mathrm{s}$, suggesting a triplet character of this state. This might imply that the CS states in dyads 1 are formed from the $\mathrm{P}^{-}{ }^{3} \mathrm{C}_{60}$ state. Comparison of the calculated energy differences between the $\mathrm{P}_{-}{ }^{3} \mathrm{C}_{60}$ and $\mathrm{CS}$ states (Figure 2) shows that population of the CS state is thermodynamically favored for $\mathbf{1}$ c, slightly disfavored for $\mathbf{1} \mathbf{a}$, and significantly disfavored for $\mathbf{1} \mathbf{b}$, which might explain the observed data on CS state formation in dyads 1.

Alternatively, the observed differences in the photodynamics of $1 \mathbf{a}-\mathbf{c}$ might be rationalized in the following way. The decreased fluorescence lifetimes and quantum yields in porphyrin-fullerenes $1 \mathrm{~b}$ and $1 \mathrm{c}$ compared to $1 \mathrm{a}(1.8 \mathrm{~ns}$, ca. $0.6 \%$ vs. $7.2 \mathrm{~ns}, 2.6 \%)$ suggest that competing non-radiative transition processes are favored in $\mathbf{1} \mathbf{b}, \mathbf{c}$. However, these processes seem to be different in nature. The decreased fluorescence lifetime in $\mathbf{1} \mathbf{b}$ combined with the absence of the CS state in this case can be explained in terms of facilitation of intersystem crossings within the molecule by the bromine atoms due to spin- orbital coupling (the so-called heavy atom effect ${ }^{[27]}$ ). That is to say, bromine significantly accelerates radiationless transitions between states of different multiplicities compared to porphyrin-fullerenes not bearing bromo substituents, thereby facilitating relaxation to the ground state and suppressing population of the CS state in $\mathbf{1} \mathbf{b}$ or decreasing its lifetime.

We indeed observed the heavy atom effect in the case of model porphyrins $10 \mathrm{a}-\mathrm{c}$ (Table 5): the lifetime of the first singlet state $S_{1}$ in porphyrin $10 \mathrm{~b}(4-\mathrm{Br})$ is only about a sixth of those for the same state in porphyrins $10 \mathrm{a}, \mathrm{c}(\mathrm{H}, 4-\mathrm{MeO})$ (Table $5 ; 1.3$ vs. 8.9, $8.0 \mathrm{~ns}$ ) and the corresponding fluorescence quantum yield ( $650 \mathrm{~nm}$ band) for $10 \mathrm{~b}$ is only a tenth of those for 10 a,c (Table 5; 0.4 vs. 3.9-4.3\%).

However, the spin-orbital coupling does not seem to be responsible for the reduced fluorescence lifetime in $1 \mathrm{c}$ compared to $\mathbf{1} \mathrm{a}$, since it lacks a heavy atom. A logical explanation implies acceleration of the ${ }^{1} \mathrm{P}-\mathrm{C}_{60}$ state decay through accelerated formation of the CS state, which is stabilized by a donor substituent at the porphyrin core in $1 \mathrm{c}$ compared to $\mathbf{1} \mathbf{a}, \mathbf{b}$. This also implies that the acceleration of intersystem crossing transitions leading to the ground state might not be the only reason for the lack of CS state formation in the case of $\mathbf{1} \mathbf{b}$. It is reasonable to assume that not only may the singlet-triplet state transition be accelerated, but also that the rate of the $\left({ }^{1} \mathrm{P}-\mathrm{C}_{60}\right)_{1} \rightarrow \mathrm{CS}$ transition is slowed down.

Analysis of the electrochemical and quantum chemical data further supported this interpretation. According to Marcus theory, ${ }^{[5]}$ the rate of the forward electron transfer depends exponentially on $-\left(\Delta G_{\mathrm{ET}}+\lambda\right)^{2} /\left(4 \lambda k_{\mathrm{B}} T\right)$, where $\lambda$ is the reorganization energy, $\Delta G_{\mathrm{ET}}$ is the Gibbs free energy of the electron transfer, $T$ is the temperature, and $k_{\mathrm{B}}$ is the Boltzmann constant. Depending on the ratio of $\Delta G_{\mathrm{ET}}$ and $\lambda$, the electron-transfer process falls either into a normal $\left(\left|\Delta G_{\mathrm{ET}}\right|<\lambda\right)$ or inverted $\left(\left|\Delta G_{\mathrm{ET}}\right|>\lambda\right)$ Marcus parabola region. In the first case, the smaller $\left|\Delta G_{\mathrm{ET}}\right|$, the slower the process, whereas in the second case the opposite is true. Hence, to compare the rates of CS state formation in $\mathbf{1} \mathbf{a}-\mathbf{c}$, one should determine $\Delta G_{\mathrm{ET}}$ and $\lambda$.

$\Delta G_{\mathrm{ET}}$ is often estimated as the difference between the energy of the $S_{0} \rightarrow S_{1}$ transition and the redox potential difference $\left(E_{\text {ox }}^{1 / 2}-E_{\text {red }}^{1 / 2} \cdot .^{[4 a, 6 a, 28]}\right.$ The former was taken from the UV/Vis spectra in dichloroethane and was the same for all three dyads. To determine the difference in redox potentials, we recorded cyclic voltammograms (CV) for films of $1 \mathrm{a}-\mathrm{c}$ in $0.1 \mathrm{M}$ $\mathrm{Et}_{4} \mathrm{NBF}_{4}$ solution in acetonitrile. Three reversible reduction peaks and one reversible oxidation peak were observed in the CVs of 1 a-c (Table 6, Figure 10). Comparison with our previous measurements for $\mathbf{1} \mathbf{a}$ in o-dichlorobenzene showed the difference in the determination of $\Delta G_{\mathrm{ET}}$ to be $0.5 \mathrm{eV}$, which is not crucial for a qualitative assessment, assuming that the difference is the same for all three compounds. Measurement of the redox potentials in films instead of conventional solution measurements has the advantage of enabling simultaneous recording of the electronic absorption spectra whilst performing CV experiments, allowing one to determine the chromophoric group involved in the redox process. Thus, upon reduction of $1 \mathrm{a}$, no changes were observed at the voltage of the first peak, but a new band appeared at around $665 \mathrm{~nm}$, close to the 


\begin{tabular}{|c|c|c|c|c|c|c|}
\hline & $\begin{array}{l}S_{0} \rightarrow S_{1} \\
{[e V]([n m])^{[a]}}\end{array}$ & $\begin{array}{l}E_{\mathrm{ox}}^{1 / 2}-E_{\text {red }}^{1 / 2} \\
{[\mathrm{~V}]^{[b]}}\end{array}$ & $\begin{array}{l}-\Delta G_{\mathrm{ET}} \\
{[\mathrm{eV}]^{[\mathrm{cl}}}\end{array}$ & $\begin{array}{l}E\left({ }^{(} \mathrm{P}-\mathrm{C}_{60}\right) \\
{[\mathrm{eV}]}\end{array}$ & $\begin{array}{l}E(\mathrm{CT}) \\
{[\mathrm{eV}]}\end{array}$ & $\begin{array}{l}-\Delta G_{\mathrm{ET}} \\
{[\mathrm{eV}]^{\mathrm{dd}]}}\end{array}$ \\
\hline $1 \mathrm{a}$ & $1.92(645)$ & 1.77 & 0.15 & 2.153 & 1.565 & 0.59 \\
\hline $1 \mathrm{~b}$ & $1.92(645)$ & 1.79 & 0.13 & 2.148 & 1.805 & 0.34 \\
\hline $1 \mathrm{c}$ & $1.92(645)$ & 1.69 & 0.24 & 2.130 & 1.406 & 0.72 \\
\hline
\end{tabular}

[a] Solution in 1,2-dichloroethane. [b] Film of 1 immersed in $0.1 \mathrm{M} \mathrm{Et}_{4} \mathrm{NBF}_{4}$ solution in $\mathrm{MeCN}, 500 \mathrm{mV} \mathrm{s}^{-1}$. [c] Estimated based on experimental data. [d] Estimated based on quantum chemical calculations.

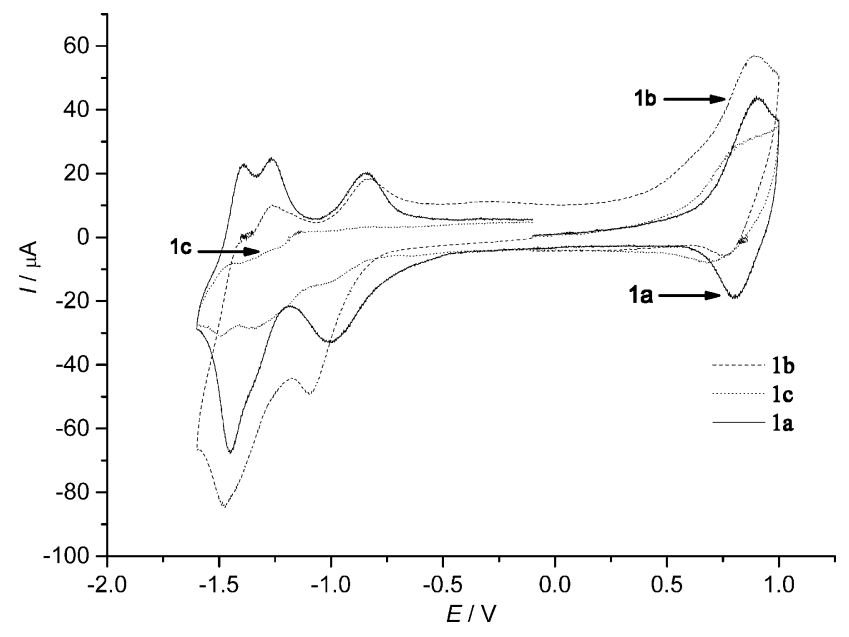

Figure 10. CVA for compounds $\mathbf{1} \mathbf{a}-\mathbf{c}$ (thin films on glassy carbon electrode immersed in $0.1 \mathrm{M} \mathrm{Et}_{4} \mathrm{NBF}_{4}$ solution in $\mathrm{MeCN}, 500 \mathrm{mV} \mathrm{s}^{-1}$ ).

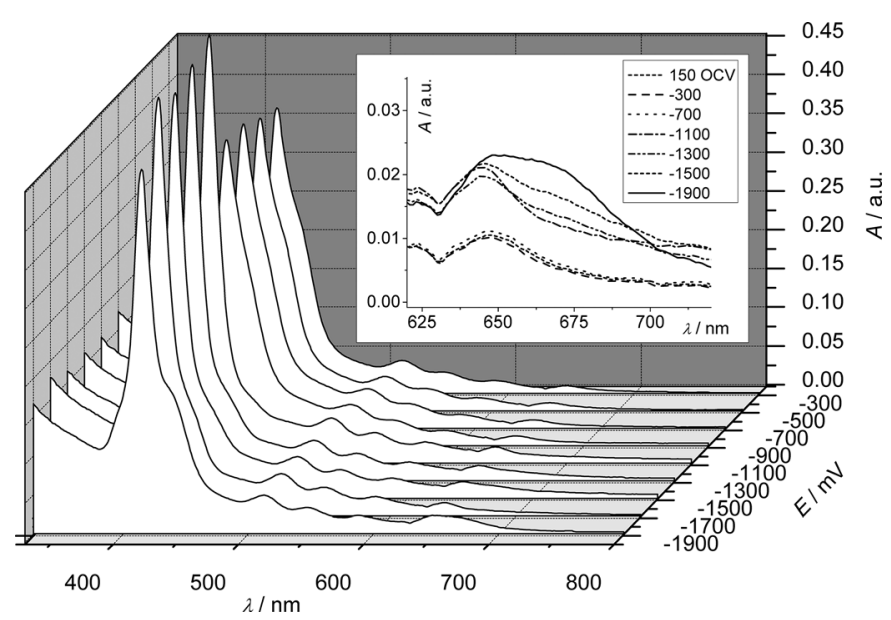

Figure 11. Measurement of UV/Vis spectrum of $1 \mathbf{a}$ film at different potentials. A new band appears at around $665 \mathrm{~nm}$ upon reduction.

onset voltage of the second peak and attained maximum intensity at the peak voltage of the second peak seen in the CV (Figures 11 and 12). According to our previous findings, ${ }^{[29]}$ the band at $665 \mathrm{~nm}$ is typical of a reduced porphyrin moiety. Hence, the first peak corresponds to reduction of the fullerene core, and the second peak corresponds to reduction of the

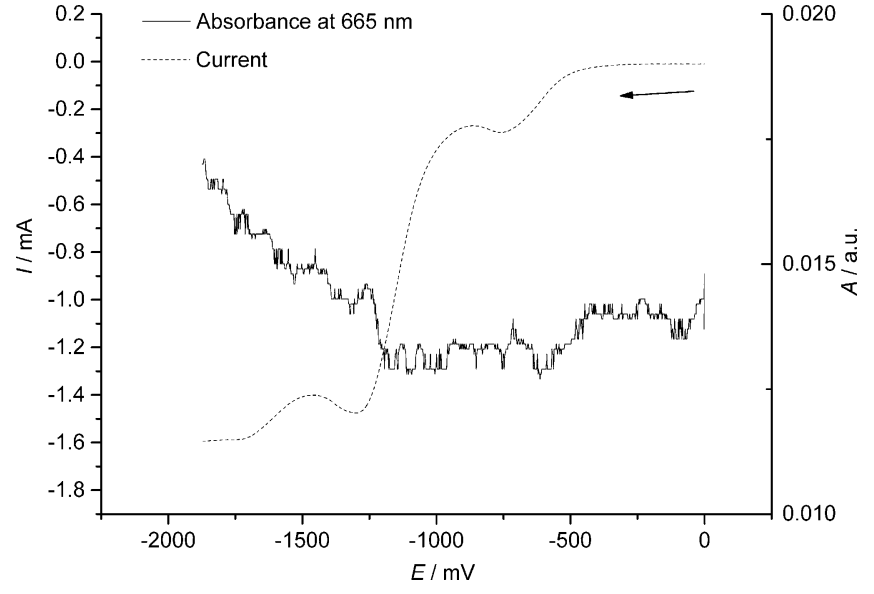

Figure 12. Measurement of absorption of $1 \mathrm{a}$ film at $665 \mathrm{~nm}$ upon reduction.

porphyrin moiety. Due to the structural similarity, these assignments could be extrapolated to $\mathbf{1} \mathbf{b}, \mathbf{c}$.

Alternatively, as the main change in energy in this process is due to the transition between excited electronic states of the molecule, $\Delta G_{\mathrm{ET}}$ can also be estimated as the difference in energies of the ${ }^{1} \mathrm{P}-\mathrm{C}_{60}$ and CS states. Both of these assessments for compounds $1 \mathbf{a}-\mathbf{c}$ are summarized in Table 6 . According to our previous assessments, ${ }^{[6]} \lambda$ for compounds 1 should fall within the range 1.1-1.6 eV in 1,2-dichloroethane, which is larger than any of the values for $-\Delta G_{\mathrm{ET}}$ given in Table 6 . Thus, the forward electron-transfer process for this series proceeds in the normal Marcus parabola region, that is, the rate of the forward electron transfer decreases with the decrease of $\left|\Delta G_{\mathrm{ET}}\right|$. Analysis of the data in Table 6 shows that the value of $\left|\Delta G_{\mathrm{ET}}\right|$ is smallest in the case of the Br-substituted compound $\mathbf{1} \mathbf{b}$, with the difference being more prominent in the case of $-\Delta G_{\mathrm{ET}}$ estimated on the basis of quantum chemical calculations $(0.59,0.34$, and $0.72 \mathrm{eV}$ for $\mathbf{1} \mathbf{a}, \mathbf{1} \mathbf{b}$, and $\mathbf{1} \mathbf{c}$, respectively). The difference in the case of $-\Delta G_{\mathrm{ET}}$ estimated on the basis of electrochemical and spectroscopic data $(0.15,0.13$, and $0.24 \mathrm{eV}$, respectively) is less prominent but follows the same trend. Hence, the introduction of a bromo substituent on the phenyl ring in the meso position of the porphyrin system decreases the forward electron-transfer rate by decreasing $\left|\Delta G_{\mathrm{ET}}\right|$ compared to the unsubstituted (1 a) and $p$-MeO-substituted (1 c) analogues. Considering that the competing transitions from $\left({ }^{1} \mathrm{P}-\mathrm{C}_{60}\right)_{1}$ to the states other than the CS state (such as $\left.\left({ }^{3} \mathrm{P}-\mathrm{C}_{60}\right)_{1}\right)$ are not affected by this substitution, they become the prevailing route for the decay of the $\left({ }^{1} \mathrm{P}-\mathrm{C}_{60}\right)_{1}$ state in $\mathbf{1} \mathbf{b}$.

\section{Conclusion}

In conclusion, it has been demonstrated that porphyrin-fullerene dyads connected through a rigid pyrrolo[3,4-c]pyrrolic linker are capable of forming charge-separated states with a lifetime of 2-4 $\mu \mathrm{s}$, which is among the best results obtained for two-component covalently linked porphyrin-fullerene ensembles. It has been shown that the choice of appropriate substituents on the porphyrin fragment is crucial for achieving 
a long lifetime of the CS state in a dyad. Thus, a $p-\mathrm{MeO}$ group on the meso-phenyl ring increases the lifetime of the CS state, whereas a $p$-Br substituent prevents the formation of the CS state or reduces its lifetime below the nanosecond range. According to TD DFT calculations, this might be explained in terms of the effect of the substituent on the energy of the CS state, with electron-donating substituents lowering it and electron-accepting substituents raising it, thus favoring or disfavoring the population of the CS state compared to the competing photophysical processes. Overall, the approach disclosed in the present work, involving analysis of TD DFT-calculated energy levels of excited states in porphyrin-fullerenes, may be applied for selecting the appropriate substitution pattern in porphyrin-fullerenes in order to create promising candidates for photovoltaic or photocatalytic applications.

\section{Experimental Section}

General methods: IR spectra were recorded on a Shimadzu IRAffinity-1 FTIR spectrometer with samples in $\mathrm{KBr} .{ }^{1} \mathrm{H}$ (300 or $400 \mathrm{MHz}$ ) and ${ }^{13} \mathrm{C}(75$ or $100 \mathrm{MHz})$ NMR spectra were determined in $\mathrm{CDCl}_{3},\left[\mathrm{D}_{6}\right] \mathrm{DMSO}$, or $\mathrm{C}_{6} \mathrm{D}_{6}$ on Bruker 400 Avance and Bruker DPX 300 spectrometers. Chemical shifts $(\delta)$ are reported in ppm downfield from tetramethylsilane. HRMS was performed using a Bruker MaXis Q-TOF mass spectrometer. The reactions under microwave irradiation were carried out in a sealed flask in a Minotav ${ }^{\circledR}-2$ microwave oven for laboratory experiments. Flash chromatography was performed on silica $(0.040-0.063 \mathrm{~mm})$. TLC analysis was performed on glass-backed plates coated with a $0.2 \mathrm{~mm}$ silica layer containing UV indicator 60F254. Quantum chemical calculations were performed using the Gaussian 09 program package.

Electrochemistry: In situ spectroscopic measurements were performed in a cell that was open to the air. Cyclic voltammetry measurements were performed in a hermetically sealed three-electrode cell at $25^{\circ} \mathrm{C}$. To remove dissolved oxygen, extra purity grade nitrogen $(99.999 \%$, Lentekhgaz) was bubbled through the solutions. Electrochemical measurements were carried out in $0.1 \mathrm{M} \mathrm{Et}_{4} \mathrm{~N}^{+} \mathrm{BF}_{4}^{-}$ solution in $\mathrm{CH}_{3} \mathrm{CN}$ in a cell consisting of a working electrode (glassy carbon disk, $0.07 \mathrm{~cm}^{2}$, or ITO glass, $2 \mathrm{~cm}^{2}$ ), a counter electrode (platinum plate), and a reference electrode (BAS MF-2062 $\mathrm{Ag} / 0.1 \mathrm{M} \mathrm{AgNO}_{3}$ solution in $\mathrm{CH}_{3} \mathrm{CN}$ or $\mathrm{Ag}$ wire, calibrated by $1 \times$ $10^{-3} \mathrm{M}$ ferrocene external standard as a pseudo-reference electrode). However, for consistency, all potentials are quoted versus an aqueous $\mathrm{Ag} / \mathrm{AgCl}(\mathrm{KCl}$ sat.) reference electrode. Electrochemical measurements were performed with IPC-PRO (Volta, Russia) and PAR273 (Princeton Applied Research, USA) potentiostats/galvanostats. UV/Vis spectra were recorded on a Shimadzu UV-1700 (Japan) spectrophotometer. Films were directly prepared on the electrodes by evaporation of the solvent from a solution in $\mathrm{CH}_{2} \mathrm{Cl}_{2}$ (ca. 1 wt.\%).

Physical measurements: Steady-state UV/Vis absorption spectra were measured on a Perkin-Elmer Lambda 1050 spectrophotometer. Fluorescence spectra and fluorescence lifetimes were measured on a Horiba Fluorolog-3 spectrofluorimeter. Nanosecond time-resolved absorption spectroscopy experiments were performed using the original experimental set-up. The excitation source was the second harmonic $(532 \mathrm{~nm}, 7 \mathrm{~ns}, 2-6 \mathrm{~mJ}$ per pulse, $50 \mathrm{~Hz}$ ) of an Nd:YAG laser (Innolas Spitlight 2000). A 75 W xenon arc lamp was used as the probe source. The probe and pump beams were transmitted perpendicularly to one another through the $1 \mathrm{~cm}$ quartz cuvette containing the sample solution. The probe and pump beam diameters were $8 \mathrm{~mm}$ at the sample position. After passage through the samples, the probe beam was dispersed through a double monochromator (Standa MSA-130) and detected using a photomultiplier tube connected to a digital oscilloscope (Agilent Technologies InfiniiVision DS07054B). Data from the digital oscilloscope (2048 averaged scans) were analyzed using Origin 9.0 software. All measurements were performed at room temperature $\left(22 \pm 2^{\circ} \mathrm{C}\right)$

Synthesis: Compounds $2 a_{,}{ }^{[6 b]} \mathbf{4}^{[23 b]} \mathbf{6}^{[23 b]} 7,{ }^{[30]}$ and $\mathbf{8} d^{[13]}$ were obtained according to known procedures. Porphyrins $\mathbf{2} \mathbf{b}$ - $\mathbf{d}$ were obtained analogously to compound $\mathbf{2} \mathrm{a}^{\left[{ }^{[6 b]}\right.}$ The reaction times for the condensation step and the yields are given in the main text.

Porphyrin 2 b: Violet solid. ' $\mathrm{H}$ NMR $\left(400 \mathrm{MHz}, \mathrm{CDCl}_{3}\right): \delta=-2.82(\mathrm{~s}$, $2 \mathrm{H}$; NH), $7.02\left(\mathrm{~s}, 2 \mathrm{H}\right.$; CH $\left.{ }^{\text {maleim}}\right), 7.79$ (pseudo d, $J=8.2 \mathrm{~Hz}, 2 \mathrm{H}$; $\mathrm{CH}^{\text {arom }}$ ), 7.91 (pseudo $\mathrm{d}, J=8.2 \mathrm{~Hz}, 6 \mathrm{H} ; \mathrm{CH}^{\text {arom }}$ ), 8.09 (pseudo $\mathrm{d}, J=$ $\left.8.2 \mathrm{~Hz}, 6 \mathrm{H} ; \mathrm{CH}^{\text {arom }}\right), 8.32$ (pseudo $\left.\mathrm{d}, J=8.2 \mathrm{~Hz}, 2 \mathrm{H} ; \mathrm{CH}^{\text {arom }}\right), 8.86(\mathrm{~m}$, $\left.6 \mathrm{H} ; \mathrm{CH}^{\text {pyrrol }}\right), 8.93 \mathrm{ppm}$ (pseudo $\left.\mathrm{d}, J=4.8 \mathrm{~Hz}, 2 \mathrm{H} ; \mathrm{CH}^{\text {pyrrol }}\right) ;{ }^{13} \mathrm{CNMR}^{\circ}$ $\left(100 \mathrm{MHz}, \mathrm{CDCl}_{3}\right): \delta=118.9,119.0,119.3,122.6,124.0,130.0,131.2$, 134.5, 135.0, 135.8, 140.9, 141.4, $169.6 \mathrm{ppm}(\mathrm{C}=0)$; IR (KBr): $\tilde{v}=$ $1717(\mathrm{C}=\mathrm{O}), \quad 3316 \mathrm{~cm}^{-1}(\mathrm{NH})$; HRMS (ESI-TOF): $\mathrm{m} / \mathrm{z}$ calcd for $\mathrm{C}_{48} \mathrm{H}_{29} \mathrm{Br}_{3} \mathrm{~N}_{5} \mathrm{O}_{2}{ }^{+}[\mathrm{M}+\mathrm{H}]^{+}$: 943.9866 ; found: 943.9855 .

Porphyrin $2 \mathrm{c}$ : Violet solid. ${ }^{1} \mathrm{H}$ NMR $\left(400 \mathrm{MHz}, \mathrm{CDCl}_{3}\right): \delta=-2.73(\mathrm{~s}$, $2 \mathrm{H} ; \mathrm{NH}), 4.13\left(\mathrm{~s}, 9 \mathrm{H} ; \mathrm{OCH}_{3}\right), 7.00\left(\mathrm{~s}, 2 \mathrm{H} ; \mathrm{CH}^{\text {maleim }}\right), 7.28-7.33(\mathrm{~m}$, $\left.6 \mathrm{H} ; \mathrm{CH}^{\text {arom }}\right), 7.79-7.81\left(\mathrm{~m}, 2 \mathrm{H} ; \mathrm{CH}^{\text {arom }}\right), 8.14-8.17\left(\mathrm{~m}, 6 \mathrm{H} ; \mathrm{CH}^{\text {arom }}\right)$, 8.34-8.36 (m, $\left.2 \mathrm{H} ; \mathrm{CH}^{\text {arom }}\right), 8.89-8.92 \mathrm{ppm}\left(\mathrm{m}, 8 \mathrm{H} ; \mathrm{CH}^{\text {pyrrol }}\right) ;{ }^{13} \mathrm{C}$ NMR $\left(100 \mathrm{MHz}, \mathrm{CDCl}_{3}\right): \delta=55.6,112.3,118.4,120.0,120.2,124.0,131.0$, 134.4, 134.5, 134.6, 135.1, 135.6, 141.9, 159.4, $169.7 \mathrm{ppm}(\mathrm{C}=\mathrm{O})$; IR (KBr): $\tilde{v}=1717(\mathrm{C}=\mathrm{O}), 3315 \mathrm{~cm}^{-1}(\mathrm{NH})$; HRMS (ESI-TOF): $\mathrm{m} / \mathrm{z}$ calcd for $\mathrm{C}_{51} \mathrm{H}_{38} \mathrm{~N}_{5} \mathrm{O}_{5}{ }^{+}[\mathrm{M}+\mathrm{H}]^{+}$: 800.2867; found: 800.2865.

Porphyrin $2 \mathrm{~d}$ : lodine $(150 \mathrm{mg}, 0.6 \mathrm{mmol})$ was added to a solution of aldehyde 7 (300 mg, $1.5 \mathrm{mmol})$, aldehyde $8 \mathbf{d ~}(1.086 \mathrm{~g}$, $4.5 \mathrm{mmol})$, and pyrrole $(402 \mathrm{mg}, 6 \mathrm{mmol})$ in $\mathrm{CH}_{2} \mathrm{Cl}_{2}(600 \mathrm{~mL})$. The reaction mixture was heated to $30^{\circ} \mathrm{C}$ and stirred at this temperature for $3 \mathrm{~h}$. Thereafter, chloranil $(1.107 \mathrm{~g}, 4.5 \mathrm{mmol})$ was added and the resulting mixture was stirred at $30^{\circ} \mathrm{C}$ for a further $10 \mathrm{~min}$ and then allowed to cool to room temperature. Perchlorinated hydroquinone was removed by washing the reaction mixture with $10 \%$ aqueous $\mathrm{NaOH}(110 \mathrm{~mL})$. The organic layer was washed with water and brine and dried over $\mathrm{Na}_{2} \mathrm{SO}_{4}$. The desiccant was filtered off and the solvent was removed in vacuo. Column chromatography (silica gel; ethyl acetate/petroleum ether, 1:4 to 1:2) of the residue followed by recrystallization of the crude product from $\mathrm{Et}_{2} \mathrm{O}$ / hexane gave porphyrin $\mathbf{2 d}(159 \mathrm{mg}, 10 \%)$ as purple crystals. M.p. $>400{ }^{\circ} \mathrm{C} ;{ }^{1} \mathrm{H}$ NMR $\left(300 \mathrm{MHz},\left[\mathrm{D}_{6}\right] \mathrm{DMSO}\right): \delta=-2.95(\mathrm{~s}, 2 \mathrm{H} ; \mathrm{NH})$, $1.41\left(\mathrm{~s}, 27 \mathrm{H} ; \mathrm{CH}_{3}\right), 4.88\left(\mathrm{~s}, 6 \mathrm{H} ; \mathrm{CH}_{2}\right), 7.35(\mathrm{~s}, 2 \mathrm{H} ; \mathrm{CH}-\mathrm{C}(\mathrm{N})=0), 7.35-$ $7.45\left(\mathrm{~m}, 3 \mathrm{H} ; \mathrm{H}_{\mathrm{ar}}\right), 7.65-7.95\left(\mathrm{~m}, 11 \mathrm{H} ; \mathrm{HC}_{\mathrm{ar}}\right), 8.25-8.35\left(\mathrm{~m}, 2 \mathrm{H} ; \mathrm{HC}_{\mathrm{ar}}\right)$,

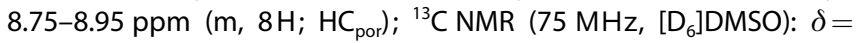
$27.7\left(\mathrm{CH}_{3}\right), 65.0\left(\mathrm{CMe}_{3}\right), 81.5\left(\mathrm{CH}_{2}\right), 114.5,114.6,119.1,119.7,120.68$, 120.73, 124.8, 127.8, 127.9, 131.6, 131-132 (brs), 134.5, 134.9, $140.2,142.3,156.2\left(C_{\text {arom }}\right), 168.0(C=0), 170.1$ ppm $(C=0)$; IR (neat, ATR): $\tilde{v}=3315(\mathrm{NH}), 1749(\mathrm{C}=0), 1715 \mathrm{~cm}^{-1}(\mathrm{C}=\mathrm{O})$; HRMS (ESI-TOF): $\mathrm{m} / \mathrm{z}$ calcd for $\mathrm{C}_{66} \mathrm{H}_{62} \mathrm{~N}_{5} \mathrm{O}_{11}{ }^{+}[\mathrm{M}+\mathrm{H}]^{+}$: 1100.4440; found: 1100.4439 .

Typical procedure for the synthesis of compounds $5 \mathrm{a}-\mathrm{c}$ : A mixture of aziridine $6(22 \mathrm{mg}, 0.049 \mathrm{mmol})$ and porphyrin $2 \mathrm{a}(35 \mathrm{mg}$, $0.049 \mathrm{mmol}$ ) in dry benzene was heated under reflux for $37 \mathrm{~h}$. Upon consumption of $\mathbf{2} \mathrm{a}$ in the reaction mixture (TLC control), the solvent was removed in vacuo and the products were isolated by column chromatography (silica gel, $25 \mathrm{~g} ; \mathrm{CH}_{2} \mathrm{Cl}_{2} / \mathrm{EtOAc}$, gradient) to give mono-adduct 5 a ( $23 \mathrm{mg}, 0.020 \mathrm{mmol}, 41 \%)$ and a mixture of diastereomeric bis-adducts 9 a $(22 \mathrm{mg}, 0.012 \mathrm{mmol}, 24 \%$ (based on 6) or $48 \%$ (based on $\mathbf{2 a}$ )). 
Compound $5 \mathrm{a}$ : Violet solid. ${ }^{1} \mathrm{H} \mathrm{NMR}\left(400 \mathrm{MHz}, \mathrm{CDCl}_{3}\right): \delta=-2.78$ $(\mathrm{s}, 2 \mathrm{H} ; \mathrm{NH}), 1.20\left(\mathrm{t}, J=7.1 \mathrm{~Hz}, 3 \mathrm{H} ; \mathrm{CH}_{3}\right), 1.35\left(\mathrm{t}, J=7.1 \mathrm{~Hz}, 9 \mathrm{H} ; \mathrm{CH}_{3}\right)$, $3.05\left(\mathrm{~s}, 2 \mathrm{H} ; \mathrm{CH}^{\text {azir }}\right), 3.85\left(\mathrm{~d}, J=8.2 \mathrm{~Hz}, 1 \mathrm{H} ; \mathrm{CH}^{\text {pyrrolid }}\right), 4.14-4.23(\mathrm{~m}$, $\left.2 \mathrm{H}+1 \mathrm{H} ; \mathrm{CH}_{2}+\mathrm{CH}^{\text {pyrrolid }}\right), 4.27-4.37\left(\mathrm{~m}, 6 \mathrm{H} ; \mathrm{CH}_{2}\right), 5.03(\mathrm{~d}, J=$ $\left.10.2 \mathrm{~Hz}, 1 \mathrm{H} ; \mathrm{CH}^{\text {pyrrolid }}\right), 5.32\left(\mathrm{~s}, 1 \mathrm{H} ; \mathrm{CH}^{\text {pyrrolid }}\right), 6.80\left(\mathrm{~m}, 2 \mathrm{H} ; \mathrm{CH}^{\text {arom }}\right)$, $7.00\left(\mathrm{~m}, 2 \mathrm{H} ; \mathrm{CH}^{\text {arom }}\right), 7.73-7.79\left(\mathrm{~m}, 11 \mathrm{H} ; \mathrm{CH}^{\text {arom }}\right), 8.23(\mathrm{~m}, 6 \mathrm{H}$; $\left.\mathrm{CH}^{\text {arom }}\right), 8.34\left(\mathrm{~m}, 2 \mathrm{H} ; \mathrm{CH}^{\text {arom }}\right), 8.87 \mathrm{ppm}\left(\mathrm{m}, 8 \mathrm{H} ; \mathrm{CH}^{\text {pyrrol }}\right) ;{ }^{13} \mathrm{C} \mathrm{NMR}$ $\left(100 \mathrm{MHz}, \mathrm{CDCl}_{3}\right): \delta=14.53\left(\mathrm{C}^{\mathrm{CH} 3}\right), 14.56\left(\mathrm{C}^{\mathrm{CH} 3}\right), 14.61\left(\mathrm{C}^{\mathrm{CH} 3}\right), 43.5$ $\left(C^{\text {azir }}\right), 43.7\left(C^{\text {azir }}\right), 47.4\left(C^{\text {pyrrolid }}\right), 49.3\left(C^{\text {pyrrolid }}\right), 62.2\left(C^{\mathrm{CH} 2}\right), 62.3\left(C^{\mathrm{CH} 2}\right)$, $62.7\left(\mathrm{C}^{\mathrm{CH} 2}\right), 64.9$ ( $\left.\mathrm{C}^{\text {pyrrolid }}\right), 65.7$ ( $\left.\mathrm{C}^{\text {pyrrolid }}\right), 117.8,118.9,120.7,120.9$, 121.4, 125.0, 127.1, 128.2, 131.7, 135.0, 135.5, 141.6, 142.5, 143.2, $145.1\left(C^{\text {arom }}\right), 167.4,170.5,171.2,175.0,175.2 \mathrm{ppm}(C=0) ; I R(K B r)$ : $\tilde{v}=1720(\mathrm{C}=\mathrm{O}), 3316 \mathrm{~cm}^{-1}(\mathrm{NH}) ;$ HRMS (ESI-TOF): $\mathrm{m} / \mathrm{z}$ calcd for $\mathrm{C}_{70} \mathrm{H}_{60} \mathrm{~N}_{7} \mathrm{O}_{10}{ }^{+}[M+\mathrm{H}]^{+}$: 1158.4396; found: 1158.4392 .

Compound 9a: ${ }^{1} \mathrm{H}$ NMR $\left(400 \mathrm{MHz}, \mathrm{CDCl}_{3}\right): \delta=-2.78(\mathrm{~s}, 4 \mathrm{H}$; $\mathrm{NH})$, 1.27-1.25 (m, 6H; $\left.\mathrm{CH}_{3}\right), 1.35\left(\mathrm{t}, J=7.2 \mathrm{~Hz}, 3 \mathrm{H} ; \mathrm{CH}_{3}\right), 1.38(\mathrm{t}, J=$ $\left.7.2 \mathrm{~Hz}, 3 \mathrm{H} ; \mathrm{CH}_{3}\right), 3.84\left(\mathrm{~d}, J=8.6 \mathrm{~Hz}, 2 \mathrm{H} ; \mathrm{CH}^{\text {pyrrolid }}\right), 4.11-4.23(\mathrm{~m}, 4 \mathrm{H}$ $\left.+2 \mathrm{H} ; \mathrm{CH}_{2}+\mathrm{CH}^{\text {pyrrolid }}\right), 4.30-4.39\left(\mathrm{~m}, 4 \mathrm{H} ; \mathrm{CH}_{2}\right), 5.06(\mathrm{~d}, J=9.5 \mathrm{~Hz}$, $\left.2 \mathrm{H} ; \mathrm{CH}^{\text {pyrrolid }}\right), 5.31+5.33\left(\mathrm{~s}+\mathrm{s}, 2 \mathrm{H} ; \mathrm{CH}^{\text {pyrrolid }}\right), 6.87\left(\mathrm{~s}, 4 \mathrm{H} ; \mathrm{CH}^{\text {arom }}\right)$, 7.75-7.79 $\left(\mathrm{m}, 22 \mathrm{H} ; \mathrm{CH}^{\text {arom }}\right), 8.23-8.25\left(\mathrm{~m}, 12 \mathrm{H} ; \mathrm{CH}^{\text {arom }}\right), 8.33-8.36$ $\left(\mathrm{m}, 4 \mathrm{H} ; \mathrm{CH}^{\text {arom }}\right), 8.87-8.88 \mathrm{ppm}\left(\mathrm{m}, 16 \mathrm{H} ; \mathrm{CH}^{\text {pyrrol }}\right) ; \mathrm{HRMS}$ (ESI-TOF): $\mathrm{m} / \mathrm{z}$ calcd for $\mathrm{C}_{118} \mathrm{H}_{92} \mathrm{~N}_{12} \mathrm{O}_{12}{ }^{2+}[M+2 \mathrm{H}]^{2+}$ : 934.3473; found: 934.3476.

Compounds $\mathbf{5 b}$ and $\mathbf{9 b}$ : Following the typical procedure with aziridine $6(17 \mathrm{mg}, 0.037 \mathrm{mmol})$ and porphyrin 2 b $(35 \mathrm{mg}$, $0.037 \mathrm{mmol})$ gave mono-adduct $5 \mathbf{b ~}(22 \mathrm{mg}, 0.016 \mathrm{mmol}, 43 \%)$ and bis-adduct $9 \mathrm{~b}$ ( $24 \mathrm{mg}, 0.010 \mathrm{mmol}, 28 \%$ (based on 6 ) or $56 \%$ (based on $\mathbf{2}$ b)).

Data for $5 \boldsymbol{b}$ : Violet solid. ${ }^{1} \mathrm{H}$ NMR $\left(400 \mathrm{MHz}, \mathrm{C}_{6} \mathrm{D}_{6}\right): \delta=-2.32(\mathrm{~s}$, $2 \mathrm{H} ; \mathrm{NH}), 0.78\left(\mathrm{t}, J=7.2 \mathrm{~Hz}, 3 \mathrm{H} ; \mathrm{CH}_{3}\right), 0.96\left(\mathrm{t}, J=7.2 \mathrm{~Hz}, 3 \mathrm{H} ; \mathrm{CH}_{3}\right)$, $0.97\left(\mathrm{t}, J=7.2 \mathrm{~Hz}, 3 \mathrm{H} ; \mathrm{CH}_{3}\right), 1.07\left(\mathrm{t}, J=7.2 \mathrm{~Hz}, 3 \mathrm{H} ; \mathrm{CH}_{3}\right), 2.55(\mathrm{~d}, J=$ $\left.6.6 \mathrm{~Hz}, 1 \mathrm{H} ; \mathrm{CH}^{\text {azir }}\right), 2.60\left(\mathrm{~d}, J=6.6 \mathrm{~Hz}, 1 \mathrm{H} ; \mathrm{CH}^{\text {azi }}\right), 2.91(\mathrm{~d}, J=8.1 \mathrm{~Hz}$, $\left.1 \mathrm{H} ; \mathrm{CH}^{\text {pyrrolid }}\right), 3.53-3.58\left(\mathrm{~m}, 1 \mathrm{H} ; \mathrm{CH}^{\text {pyrrolid }}\right), 3.79-3.82\left(\mathrm{~m}, 2 \mathrm{H} ; \mathrm{CH}_{2}\right)$, 3.97-4.03 (m, 4H; $\left.\mathrm{CH}_{2}\right), 4.14-4.27\left(\mathrm{~m}, 2 \mathrm{H} ; \mathrm{CH}_{2}\right), 5.12(\mathrm{~d}, J=9.9 \mathrm{~Hz}$, $\left.1 \mathrm{H} ; \mathrm{CH}^{\text {pyrrolid }}\right), 5.43\left(\mathrm{~s}, 1 \mathrm{H} ; \mathrm{CH}^{\text {pyrrolid }}\right), 6.69$ (pseudo $\mathrm{d}, J=9.2 \mathrm{~Hz}, 2 \mathrm{H}$; $\mathrm{CH}^{\text {arom }}$ ), 6.72 (pseudo $\mathrm{d}, J=9.2 \mathrm{~Hz}, 2 \mathrm{H} ; \mathrm{CH}^{\text {arom }}$ ), 7.55 (pseudo $\mathrm{d}, J=$ $7.8 \mathrm{~Hz}, 6 \mathrm{H} ; \mathrm{CH}^{\text {arom }}$ ), 7.69 (pseudo $\left.\mathrm{d}, J=8.2 \mathrm{~Hz}, 6 \mathrm{H} ; \mathrm{CH}^{\text {arom }}\right), 7.89$ (pseudo $\mathrm{d}, J=8.2 \mathrm{~Hz}, 2 \mathrm{H} ; \mathrm{CH}^{\text {arom }}$ ) 8.11 (pseudo $\mathrm{d}, J=8.2 \mathrm{~Hz}, 2 \mathrm{H}$; $\left.\mathrm{CH}^{\text {arom }}\right), 8.70$ (pseudo $\left.\mathrm{d}, J=4.7 \mathrm{~Hz}, 2 \mathrm{H} ; \mathrm{CH}^{\text {pyrol }}\right), 8.79\left(\mathrm{~s}, 4 \mathrm{H} ; \mathrm{CH}^{\text {pyrrol }}\right)$, $8.81 \mathrm{ppm}$ (pseudo d, $J=4.9 \mathrm{~Hz}, 2 \mathrm{H}$; CH$\left.{ }^{\text {pyrrol }}\right) ;{ }^{13} \mathrm{C} \mathrm{NMR}(100 \mathrm{MHz}$, $\left(\mathrm{CDCl}_{3}\right): \delta=13.75\left(\mathrm{C}^{\mathrm{CH} 3}\right), 13.79\left(\mathrm{C}^{\mathrm{CH}}\right), 42.7\left(\mathrm{C}^{\text {azir }}\right), 42.9\left(\mathrm{C}^{\text {azir }}\right), 47.1$ (C $\left.C^{\text {pyrrolid }}\right), 48.8$ ( $\left.\mathrm{C}^{\text {pyrrolid }}\right), 61.0\left(\mathrm{C}^{\mathrm{CH} 2}\right), 61.1\left(\mathrm{C}^{\mathrm{CH} 2}\right), 61.9\left(\mathrm{C}^{\mathrm{CH} 2}\right), 64.7$ (C $\left.{ }^{\text {pyrrolid }}\right), 65.5$ (C (Pyrrolid $\left.^{2}\right), 117.5,119.0,119.1,119.5,120.8,122.5,124.8$, $127.6,127.8,129.8,129.9,132.0,134.8,135.75,135.79,140.92$, $140.94,141.35,142.39,145.2\left(C^{\text {arom }}\right), 166.56,166.59,166.9,170.6$, 174.2, $174.4 \mathrm{ppm}(\mathrm{C}=\mathrm{O}) ; \mathrm{IR}(\mathrm{KBr}): \tilde{v}=1721(\mathrm{C}=\mathrm{O}), 3317 \mathrm{~cm}^{-1}(\mathrm{NH})$; HRMS (ESI-TOF): $\mathrm{m} / \mathrm{z}$ calcd for $\mathrm{C}_{70} \mathrm{H}_{57} \mathrm{Br}_{3} \mathrm{~N}_{7} \mathrm{O}_{10}{ }^{+}[\mathrm{M}+\mathrm{H}]^{+}: 1392.1712$; found: 1392.1697 .

Data for $9 \boldsymbol{b}$ : ${ }^{1} \mathrm{H}$ NMR $\left(400 \mathrm{MHz}, \mathrm{CDCl}_{3}\right): \delta=-2.94(\mathrm{~s}, 4 \mathrm{H} ; \mathrm{NH})$, 1.09-1.15 (m, 6H; $\left.\mathrm{CH}_{3}\right), 1.24-1.31\left(\mathrm{~m}, 6 \mathrm{H} ; \mathrm{CH}_{3}\right), 3.75(\mathrm{~d}, J=8.5 \mathrm{~Hz}$, $\left.2 \mathrm{H} ; \mathrm{CH}^{\text {pyrrolid }}\right), 4.07-4.13\left(\mathrm{~m}, 4 \mathrm{H}+2 \mathrm{H} ; \mathrm{CH}_{2}+\mathrm{CH}^{\text {pyrolid }}\right), 4.22-4.29$ $\left(\mathrm{m}, 4 \mathrm{H} ; \mathrm{CH}_{2}\right), 4.97\left(\mathrm{~d}, J=10.1 \mathrm{~Hz}, 2 \mathrm{H} ; \mathrm{CH}^{\text {pyrrolid }}\right), 5.21+5.23(\mathrm{~s}+\mathrm{s}$, $2 \mathrm{H}$; $\left.\mathrm{CH}^{\text {pyrrolid }}\right), 6.77-6.78\left(\mathrm{~m}, 4 \mathrm{H} ; \mathrm{CH}^{\text {arom }}\right), 7.67-7.69\left(\mathrm{~m}, 4 \mathrm{H} ; \mathrm{CH}^{\text {arom }}\right)$, 7.82-7.84 $\left(\mathrm{m}, 12 \mathrm{H} ; \mathrm{CH}^{\text {arom }}\right), 7.98-8.01\left(\mathrm{~m}, 12 \mathrm{H} ; \mathrm{CH}^{\text {arom }}\right), 8.21-8.24$ $\left(\mathrm{m}, 4 \mathrm{H} ; \mathrm{CH}^{\text {arom }}\right), 8.76\left(\mathrm{~m}, 12 \mathrm{H} ; \mathrm{CH}^{\text {pyrrol }}\right), 8.81 \mathrm{ppm}$ (pseudo $\mathrm{d}, J=$ $4.6 \mathrm{~Hz}, 4 \mathrm{H}$; $\mathrm{CH}^{\text {pyrrol }}$; HRMS (ESI-TOF): $\mathrm{m} / \mathrm{z}$ calcd for $\mathrm{C}_{118} \mathrm{H}_{86} \mathrm{Br}_{6} \mathrm{~N}_{12} \mathrm{O}_{12}{ }^{2+}[M+2 \mathrm{H}]^{2+}$ : 1168.0789; found: 1168.0762 .

Compounds $5 \mathrm{c}$ and $9 \mathrm{c}$ : Following the typical procedure with aziridine $6(27 \mathrm{mg}, 0.060 \mathrm{mmol})$ and porphyrin $2 \mathrm{c}(48 \mathrm{mg}, 0.060 \mathrm{mmol})$ gave mono-adduct $5 \mathrm{c}(33 \mathrm{mg}, 0.026 \mathrm{mmol}, 44 \%)$ and bis-adduct 9 c (29 mg, $0.014 \mathrm{mmol}, 23 \%$ (based on 6) or $46 \%$ (based on $2 \mathrm{c}$ )).
Data for $5 \mathrm{c}$ : Violet solid. 'H NMR $\left(400 \mathrm{MHz}, \mathrm{CDCl}_{3}\right): \delta=-2.05(\mathrm{~s}$, $2 \mathrm{H} ; \mathrm{NH}), 0.77\left(\mathrm{t}, J=7.1 \mathrm{~Hz}, 3 \mathrm{H} ; \mathrm{CH}_{3}\right), 0.958\left(\mathrm{t}, J=7.1 \mathrm{~Hz}, 3 \mathrm{H} ; \mathrm{CH}_{3}\right)$, 0.964 (t, J=7.1 Hz, 3H; $\left.\mathrm{CH}_{3}\right), 1.06\left(\mathrm{t}, J=7.1 \mathrm{~Hz}, 3 \mathrm{H} ; \mathrm{CH}_{3}\right), 2.54(\mathrm{~d}$, $\left.J=6.6 \mathrm{~Hz}, 1 \mathrm{H} ; \mathrm{CH}^{\text {azir }}\right), 2.60\left(\mathrm{~d}, J=6.6 \mathrm{~Hz}, 1 \mathrm{H} ; \mathrm{CH}^{\text {azir }}\right), 2.89(\mathrm{~d}, J=$ $\left.8.5 \mathrm{~Hz}, 1 \mathrm{H} ; \mathrm{CH}^{\text {pyrrolid }}\right), 3.53-3.57\left(\mathrm{~m}, 1 \mathrm{H}+9 \mathrm{H} ; \mathrm{CH}^{\text {pyrrolid }}+\mathrm{OMe}\right)$, 3.76-3.84 (m, 2H; $\left.\mathrm{CH}_{2}\right), 3.97-4.03\left(\mathrm{~m}, 4 \mathrm{H} ; \mathrm{CH}_{2}\right), 4.11-4.26(\mathrm{~m}, 2 \mathrm{H}$; $\left.\mathrm{CH}_{2}\right), 5.12\left(\mathrm{~d}, J=10.1 \mathrm{~Hz}, 1 \mathrm{H} ; \mathrm{CH}^{\text {pyrrolid }}\right), 5.43\left(\mathrm{~s}, 1 \mathrm{H} ; \mathrm{CH}^{\text {pyrrolid }}\right), 6.68$ (pseudo $d, J=9.0 \mathrm{~Hz}, 2 \mathrm{H} ; \mathrm{CH}^{\text {arom}}$ ), 6.73 (pseudo $\mathrm{d}, J=9.0 \mathrm{~Hz}, 2 \mathrm{H}$; $\mathrm{CH}^{\text {arom }}$ ), 7.07 (pseudo $\mathrm{d}, J=8.2 \mathrm{~Hz}, 6 \mathrm{H} ; \mathrm{CH}^{\text {arom }}$ ), 7.87 (pseudo $\mathrm{d}, J=$ $\left.8.2 \mathrm{~Hz}, 2 \mathrm{H} ; \mathrm{CH}^{\text {arom }}\right), 8.05$ (pseudo $\mathrm{d}, J=8.4 \mathrm{~Hz}, 6 \mathrm{H} ; \mathrm{CH}^{\text {arom }}$ ), 8.15 (pseudo d, $J=8.2 \mathrm{~Hz}, 2 \mathrm{H} ; \mathrm{CH}^{\text {arom }}$ ), 8.84 (pseudo d, $J=4.9 \mathrm{~Hz}, 2 \mathrm{H}$; $\left.\mathrm{CH}^{\text {pyrrol }}\right), 8.98$ (pseudo $\left.\mathrm{d}, J=4.7 \mathrm{~Hz}, 2 \mathrm{H} ; \mathrm{CH}^{\text {pyrrol }}\right), 9.07 \mathrm{ppm}(\mathrm{s}, 4 \mathrm{H}$; $\left.\mathrm{CH}^{\text {pyrrol }}\right) ;{ }^{13} \mathrm{C}$ NMR $\left(100 \mathrm{MHz}, \mathrm{CDCl}_{3}\right): \delta=13.8\left(\mathrm{C}^{\mathrm{CH} 3}\right), 13.9\left(\mathrm{C}^{\mathrm{CH} 3}\right), 42.8$, $43.0,47.2,48.8,54.8\left(\mathrm{C}^{\mathrm{OCH} 3}\right), 61.0\left(\mathrm{C}^{\mathrm{CH} 2}\right), 61.1\left(\mathrm{C}^{\mathrm{CH} 2}\right), 61.9\left(\mathrm{C}^{\mathrm{CH} 2}\right), 64.8$, $65.6,112.4\left(C^{\text {arom }}\right), 117.5,118.7,120.4,120.6,120.8,124.8,131.9$, $134.8,134.9,135.0,135.7,135.8,141.5,143.1,145.3,159.7$ (Carom), $166.7,169.9,170.6,174.2,174.5 \mathrm{ppm}(\mathrm{C}=0)$; IR $(\mathrm{KBr}): \tilde{v}=1724(\mathrm{C}=$ O), $3316 \mathrm{~cm}^{-1}(\mathrm{NH})$; HRMS (ESI-TOF): $\mathrm{m} / \mathrm{z}$ calcd for $\mathrm{C}_{73} \mathrm{H}_{67} \mathrm{~N}_{7} \mathrm{O}_{13}{ }^{2+}$ $[M+2 \mathrm{H}]^{2+}$ : 624.7393 ; found: 624.7382 .

Data for $9 \mathrm{c}$ : ${ }^{1} \mathrm{H}$ NMR $\left(400 \mathrm{MHz}, \mathrm{CDCl}_{3}\right): \delta=-2.74(\mathrm{~s}, 4 \mathrm{H} ; \mathrm{NH}), 1.20$ $\left(\mathrm{t}, J=7.2 \mathrm{~Hz}, 3 \mathrm{H} ; \mathrm{CH}_{3}\right), 1.23\left(\mathrm{t}, J=7.2 \mathrm{~Hz}, 3 \mathrm{H} ; \mathrm{CH}_{3}\right), 1.35(\mathrm{t}, J=$ $\left.7.2 \mathrm{~Hz}, 3 \mathrm{H} ; \mathrm{CH}_{3}\right), 1.36\left(\mathrm{t}, J=7.2 \mathrm{~Hz}, 3 \mathrm{H} ; \mathrm{CH}_{3}\right), 3.84(\mathrm{~d}, J=8.6 \mathrm{~Hz}, 2 \mathrm{H}$; $\left.\mathrm{CH}^{\text {pyrrolid }}\right), 4.12\left(\mathrm{~s}, 18 \mathrm{H} ; \mathrm{CH}_{3} \mathrm{O}\right), 4.12-4.22\left(\mathrm{~m}, 4 \mathrm{H}+2 \mathrm{H} ; \mathrm{CH}_{2}+\right.$ $\left.\mathrm{CH}^{\text {pyrrolid }}\right), 4.31-4.38\left(\mathrm{~m}, 4 \mathrm{H} ; \mathrm{CH}_{2}\right), 5.06\left(\mathrm{~d}, J=9.9 \mathrm{~Hz}, 2 \mathrm{H} ; \mathrm{CH}^{\text {pyrrolid }}\right)$, $5.31+5.32\left(\mathrm{~s}+\mathrm{s}, 2 \mathrm{H} ; \mathrm{CH}^{\text {pyrrolid }}\right), 6.88\left(\mathrm{~s}, 4 \mathrm{H} ; \mathrm{CH}^{\text {arom }}\right), 7.30-7.32(\mathrm{~m}$, $\left.12 \mathrm{H} ; \mathrm{CH}^{\text {arom }}\right), 7.75-7.77\left(\mathrm{~m}, 4 \mathrm{H} ; \mathrm{CH}^{\text {arom }}\right), 8.13-8.15\left(\mathrm{~m}, 12 \mathrm{H} ; \mathrm{CH}^{\text {arom }}\right)$, $8.32-8.35\left(\mathrm{~m}, 4 \mathrm{H} ; \mathrm{CH}^{\text {arom }}\right) 8.86-8.91 \mathrm{ppm}\left(\mathrm{m}, 16 \mathrm{H} ; \mathrm{CH}^{\text {pyrrol }}\right)$; HRMS (ESI-TOF): $\mathrm{m} / \mathrm{z}$ calcd for $\mathrm{C}_{124} \mathrm{H}_{104} \mathrm{~N}_{12} \mathrm{O}_{18}{ }^{2+}[\mathrm{M}+2 \mathrm{H}]^{2+}$ : 1024.3790; found: 1024.3776 .

Typical procedure for the synthesis of dyads $1 \mathrm{a}-\mathrm{c}$ : A mixture of porphyrin $5 \mathrm{a}(22 \mathrm{mg}, 0.019 \mathrm{mmol})$ and fullerene $C_{60}(27 \mathrm{mg}$, $0.038 \mathrm{mmol}$ ) was heated in dry chlorobenzene at $100^{\circ} \mathrm{C}$ for $18 \mathrm{~h}$. Upon consumption of $\mathbf{5}$ a (TLC control), DDQ ( $9.5 \mathrm{mg}, 0.042 \mathrm{mmol}$ ) was added and the reaction mixture was subjected to microwave activation ( $160 \mathrm{~W}$, maximum temperature attained: $\left.135^{\circ} \mathrm{C}\right)$ for $45 \mathrm{~min}$. The solvent was then removed in vacuo and the product was isolated by column chromatography to give the target porphyrin-fullerene dyad 1 a $(12 \mathrm{mg}, 0.006 \mathrm{mmol}, 34 \%)$. The ${ }^{1} \mathrm{H}$ NMR spectrum was identical to that reported previously. ${ }^{[6 \mathrm{~b}]}$

Dyad $1 \mathbf{b}$ : Following the typical procedure with porphyrin $\mathbf{5 b}$ (34 mg, $0.025 \mathrm{mmol})$ and fullerene $\mathrm{C}_{60}(35 \mathrm{mg}, 0.049 \mathrm{mmol})$ gave porphyrin-fullerene $\mathbf{1 b}(12 \mathrm{mg}, 0.006 \mathrm{mmol})$ in $23 \%$ yield. Dark solid. ${ }^{1} \mathrm{H}$ NMR $\left(400 \mathrm{MHz}, \mathrm{CDCl}_{3}\right): \delta=-2.84(\mathrm{~s}, 2 \mathrm{H} ; \mathrm{NH}), 1.26(\mathrm{t}, J=$ $\left.7.2 \mathrm{~Hz}, 6 \mathrm{H} ; \mathrm{CH}_{3}\right), 1.45\left(\mathrm{t}, J=7.2 \mathrm{~Hz}, 6 \mathrm{H} ; \mathrm{CH}_{3}\right), 4.340(\mathrm{q}, J=7.0 \mathrm{~Hz}$, $\left.2 \mathrm{H} ; \mathrm{CH}_{2}\right), 4.343\left(\mathrm{q}, J=7.0 \mathrm{~Hz}, 2 \mathrm{H} ; \mathrm{CH}_{2}\right), 4.41\left(\mathrm{q}, J=7.0 \mathrm{~Hz}, 4 \mathrm{H} ; \mathrm{CH}_{2}\right)$, $6.57\left(\mathrm{~s}, 2 \mathrm{H} ; \mathrm{CH}^{\text {pyrrolidin }}\right), 7.43-7.46\left(\mathrm{~m}, 2 \mathrm{H} ; \mathrm{CH}^{\text {arom }}\right), 7.53-7.55(\mathrm{~m}, 2 \mathrm{H}$; $\left.\mathrm{CH}^{\text {arom }}\right), 7.88-7.90\left(\mathrm{~m}, 2 \mathrm{H} ; \mathrm{CH}^{\text {arom }}\right), 7.93-7.96\left(\mathrm{~m}, 6 \mathrm{H} ; \mathrm{CH}^{\text {arom }}\right), 8.09-$ $8.12\left(\mathrm{~m}, 6 \mathrm{H} ; \mathrm{CH}^{\text {arom }}\right), 8.40-8.42\left(\mathrm{~m}, 2 \mathrm{H} ; \mathrm{CH}^{\text {arom }}\right), 8.87-8.88(\mathrm{~m}, 6 \mathrm{H}$; $\left.\mathrm{CH}^{\text {pyrrol }}\right), 9.00-9.01 \mathrm{ppm}\left(\mathrm{m}, 2 \mathrm{H} ; \mathrm{CH}^{\text {pyrrol }}\right) ;{ }^{13} \mathrm{C} \mathrm{NMR}\left(100 \mathrm{MHz}, \mathrm{CDCl}_{3}\right)$ : $\delta=169.9\left(\mathrm{CO}_{2} \mathrm{R}\right), 161.2(\mathrm{C}=\mathrm{O}), 157.9\left(\mathrm{CO}_{2} \mathrm{R}\right), 152.9\left(\right.$ cis- $\left.\mathrm{C}^{1 f}\right), 149.9$ (trans- $\left.\mathrm{C}^{1 f}\right), 147.4,146.9\left({ }^{i} \mathrm{C}_{6} \mathrm{H}_{4}, \mathrm{~A}\right), 146.2,145.9,145.4,145.31,145.21$, $145.19,145.12,145.06,144.2,144.1,143.0,142.8,142.7,142.6$, $142.5,142.0,141.72,141.70,141.6,141.4,141.0\left({ }^{i} \mathrm{C}_{6} \mathrm{H}_{4}, \mathrm{~B}\right), 139.9$,

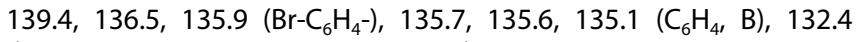
( $\left.{ }^{i} \mathrm{C}_{6} \mathrm{H}_{4}, \mathrm{~B}\right), 131.5$ (brs; porph.), $131.4\left({ }^{i} \mathrm{C}_{6} \mathrm{H}_{4}, \mathrm{~A}\right), 130.1\left(\mathrm{Br}-\mathrm{C}_{6} \mathrm{H}_{4}-\right), 128.7$ $\left(\mathrm{C}_{6} \mathrm{H}_{4}, \mathrm{~A}\right), 125.6\left(\mathrm{C}_{6} \mathrm{H}_{4}, \mathrm{~B}\right), 124.8,124.2,122.8\left({ }^{i} \mathrm{Br}-\mathrm{C}_{6} \mathrm{H}_{4}-\right), 119.8\left({ }^{i} \mathrm{C}_{6} \mathrm{H}_{4}\right.$, B), 119.1, $118.5\left(\mathrm{C}_{6} \mathrm{H}_{4}, \mathrm{~A}\right), 74.7\left(\mathrm{CH}^{\text {pyrr }}\right), 70.9\left(\mathrm{C}^{\text {q pyrr }}\right), 62.2\left(\mathrm{CH}_{2} \mathrm{O}\right), 14.3$ $\left(\mathrm{CH}_{3}\right), \quad 14.2 \mathrm{ppm}\left(\mathrm{CH}_{3}\right)$; HRMS (ESI-TOF): $\mathrm{m} / \mathrm{z}$ calcd for $\mathrm{C}_{130} \mathrm{H}_{54} \mathrm{Br}_{3} \mathrm{~N}_{7} \mathrm{O}_{10}{ }^{+}[\mathrm{M}+2 \mathrm{H}]^{2+}$ : 1054.5736; found: 1054.5720 .

Dyad $1 \mathrm{c}$ : Following the typical procedure with porphyrin $5 \mathrm{c}$ (38 mg, $0.030 \mathrm{mmol}$ ) and fullerene $\mathrm{C}_{60}(44 \mathrm{mg}, 0.061 \mathrm{mmol})$ gave porphyrin-fullerene $1 \mathrm{c}(7.5 \mathrm{mg}, 0.004 \mathrm{mmol})$ in $20 \%$ yield. Dark solid. ' ${ }^{H} \mathrm{NMR}\left(400 \mathrm{MHz}, \mathrm{CDCl}_{3}\right): \delta=-2.76(\mathrm{~s}, 2 \mathrm{H} ; \mathrm{NH}), 1.26(\mathrm{t}, J=$ 
$\left.7.0 \mathrm{~Hz}, 6 \mathrm{H} ; \mathrm{CH}_{3}\right), 1.45\left(\mathrm{t}, J=7.0 \mathrm{~Hz}, 6 \mathrm{H} ; \mathrm{CH}_{3}\right), 4.14\left(\mathrm{~s}, 9 \mathrm{H} ; \mathrm{CH}_{3} \mathrm{O}\right)$ 4.32-4.43 (m, 8H; $\left.\mathrm{CH}_{2}\right), 6.58\left(\mathrm{~s}, 2 \mathrm{H} ; \mathrm{CH}^{\text {pyrrolidin }}\right), 7.33$ (pseudo $\mathrm{d}, J=$ $\left.8.3 \mathrm{~Hz}, 6 \mathrm{H} ; \mathrm{CH}^{\text {arom }}\right), 7.45$ (pseudo $\mathrm{d}, J=8.2 \mathrm{~Hz}, 2 \mathrm{H} ; \mathrm{CH}^{\text {arom }}$ ), 7.54 (pseudo $\mathrm{d}, J=8.2 \mathrm{~Hz}, 2 \mathrm{H} ; \mathrm{CH}^{\text {arom }}$ ), 7.88 (pseudo $\mathrm{d}, J=8.1 \mathrm{~Hz}, 2 \mathrm{H}$; $\mathrm{CH}^{\text {arom }}$ ), 8.16 (pseudo $\left.\mathrm{d}, J=7.9 \mathrm{~Hz}, 6 \mathrm{H} ; \mathrm{CH}^{\text {arom }}\right), 8.42$ (pseudo $\mathrm{d}, J=$ $\left.7.8 \mathrm{~Hz}, 2 \mathrm{H} ; \mathrm{CH}^{\text {arom }}\right), 8.90-8.92\left(\mathrm{~m}, 6 \mathrm{H} ; \mathrm{CH}^{\text {pyrrol }}\right), 8.96-8.97 \mathrm{ppm}(\mathrm{m}$, $\left.2 \mathrm{H} ; \mathrm{CH}^{\text {pyrrol }}\right) ;{ }^{13} \mathrm{C}$ NMR $\left(100 \mathrm{MHz}, \mathrm{CDCl}_{3}\right): \delta=170.0(\mathrm{C}=0), 161.3(\mathrm{C}=$ O), 159.4, 157.9, 153.0, 150.1, 147.5, 146.9, 146.4, 146.2, 146.1, $145.6,145.40,145.36,145.31,145.23,144.4,142.9,142.7,142.6$, $142.1,141.9,141.8,141.7,140.1,139.6,136.7,135.9,135.7,135.2$, 134.8, 134.7, 132.1, 131.4, 131.3 (brs), 128.6, 125.6, 125.4, 124.8, $124.3,120.3,120.1,118.8,118.5\left(C^{\text {arom }}\right), 112.4,74.7\left(\mathrm{CH}^{\text {pyrr }}\right), 71.0\left(C^{\mathrm{q}}\right.$

pyrr $), 62.2\left(\mathrm{CH}_{2} \mathrm{O}\right), 55.7(\mathrm{MeO}), 14.3\left(\mathrm{CH}_{3}\right), 14.2 \mathrm{ppm}\left(\mathrm{CH}_{3}\right)$; HRMS (ESITOF): $\mathrm{m} / \mathrm{z}$ calcd for $\mathrm{C}_{133} \mathrm{H}_{62} \mathrm{~N}_{7} \mathrm{O}_{13}{ }^{+}[\mathrm{M}+\mathrm{H}]^{+}:$1964.4400; found: 1964.4399.

Dyad $1 \mathrm{~d}$ : A mixture of aziridine $4(10 \mathrm{mg}, 0.009 \mathrm{mmol})$ and porphyrin 2 d $(94 \mathrm{mg}, 0.085 \mathrm{mmol})$ in dry chlorobenzene $(7 \mathrm{~mL})$ was heated at $90^{\circ} \mathrm{C}$ for $45 \mathrm{~h}$. The solvent was then removed in vacuo and the residue was separated by flash chromatography (silica gel; toluene/ethyl acetate), which gave a crude mixture of diastereomeric trans,trans-cycloadducts $\mathbf{3} \mathbf{d}$ ( $14 \mathrm{mg}, 72 \%$ estimated yield). DDQ ( $8 \mathrm{mg}, 0.035 \mathrm{mmol}$ ) was added to the mixture of cycloadducts dissolved in dry chlorobenzene $(3 \mathrm{~mL})$ and the reaction mixture was subjected to microwave irradiation $\left(127^{\circ} \mathrm{C}, 75 \mathrm{~W}\right)$ for $90 \mathrm{~min}$. Porphyrin-fullerene $\mathbf{1} \mathbf{d}$ was isolated by flash chromatography (silica gel; toluene/ethyl acetate) and purified by HPLC (buckyprep column; toluene/ethyl acetate) to afford the target compound $1 \mathrm{~d}$ as a brown solid ( $2 \mathrm{mg}, 10 \%$ yield). ${ }^{1} \mathrm{H} \mathrm{NMR}(400 \mathrm{MHz}$, $\left.\mathrm{CDCl}_{3}\right): \delta=-2.87(\mathrm{~s}, 2 \mathrm{H} ; \mathrm{NH}), 1.23\left(\mathrm{t}, J=7.1 \mathrm{~Hz}, 6 \mathrm{H} ; 2 \times \mathrm{CH}_{3}{ }^{\mathrm{Et}}\right), 1.43$ $\left(\mathrm{t}, J=7.1 \mathrm{~Hz}, 6 \mathrm{H} ; 2 \times \mathrm{CH}_{3}{ }^{\mathrm{Et}}\right), 1.47(\mathrm{brs}, 18 \mathrm{H} ; 2 \times t \mathrm{Bu}), 1.48-1.50(\mathrm{~m}$, $9 \mathrm{H} ; \mathrm{tBu}), 4.27-4.36\left(\mathrm{~m}, 4 \mathrm{H} ; 2 \times \mathrm{CH}_{2}{ }^{\mathrm{Et}}\right), 4.38\left(\mathrm{q}, 4 \mathrm{H} ; 2 \times \mathrm{CH}_{2}{ }^{\mathrm{Et}}\right), 4.68-$ $4.72\left(\mathrm{~m}, 4 \mathrm{H} ; 2 \times \mathrm{CH}_{2} \mathrm{OAr}\right), 4.72-4.75\left(\mathrm{~m}, 2 \mathrm{H} ; \mathrm{CH}_{2} \mathrm{OAr}\right), 6.53(\mathrm{~s}, 2 \mathrm{H}$; $\left.2 \times \mathrm{HC}^{-\mathrm{C}_{60}}\right), 7.35-7.40\left(\mathrm{~m}, 3 \mathrm{H} ; \mathrm{C}^{6} \mathrm{H}^{\mathrm{A}}\right), 7.43$ (pseudo d, $J=9.0 \mathrm{~Hz}, 2 \mathrm{H}$; $\mathrm{H}^{\mathrm{E}}$ ), 7.54 (pseudo $\left.\mathrm{d}, J=9.0 \mathrm{~Hz}, 2 \mathrm{H} ; \mathrm{H}^{\mathrm{E}}\right), 7.65-7.71\left(\mathrm{~m}, 3 \mathrm{H} ; \mathrm{C}^{5} \mathrm{H}^{\mathrm{A}}\right)$, 7.71-7.75 (m, 2H; $\left.\mathrm{C}^{2} \mathrm{H}^{\mathrm{A}}\right), 7.71-7.80\left(\mathrm{brs}, 1 \mathrm{H} ; \mathrm{C}^{2} \mathrm{H}^{\mathrm{A}}\right), 7.80-7.87(\mathrm{~m}$, $3 \mathrm{H} ; \mathrm{C}^{4} \mathrm{H}^{\mathrm{A}}$ ), 7.87 (pseudo $\mathrm{d}, J=8.3 \mathrm{~Hz}, 2 \mathrm{H} ; \mathrm{H}^{\mathrm{D}}$ ), 8.41 (pseudo d, $J=$ $8.3 \mathrm{~Hz}, 2 \mathrm{H} ; \mathrm{H}^{\mathrm{D}}$ ), 8.86 (pseudo $d, J=5.2 \mathrm{~Hz}, 2 \mathrm{H} ; \mathrm{H}^{B}$ ), 8.88 (pseudo $d$, $J=5.2 \mathrm{~Hz}, 2 \mathrm{H} ; \mathrm{H}^{B}$ ), 8.90 (pseudo $\mathrm{d}, J=4.9 \mathrm{~Hz}, 2 \mathrm{H} ; \mathrm{H}^{\mathrm{C}}$ ), $8.96 \mathrm{ppm}$ (pseudo $\left.\mathrm{d}, J=4.9 \mathrm{~Hz}, 2 \mathrm{H} ; \mathrm{H}^{\mathrm{C}}\right) ;{ }^{13} \mathrm{C}$ NMR $\left(100 \mathrm{MHz}, \mathrm{CDCl}_{3}\right.$; only characteristic signals are given): $\delta=170.0,168.1,161.3,157.9,156.4$ (2x $\mathrm{CO}_{2} \mathrm{Et}, 2 \times \mathrm{CO}_{2} t \mathrm{Bu}, \mathrm{C}=\mathrm{O}$ ), the signal-to-noise ratio in the range 155 $105 \mathrm{ppm}$ precludes confident determination of the signals, 82.4 $\left(\mathrm{CH}_{2} \mathrm{OAr}\right), 74.5\left(\mathrm{CH}^{\text {pyrr }}\right), 70.8\left(\mathrm{C}^{\mathrm{q} \text { pyrr }}\right), 65.7\left(\mathrm{CMe}_{3}\right), 62.2\left(\mathrm{CH}_{2} \mathrm{O}\right), 28.0$ $\left(\mathrm{C}\left(\mathrm{CH}_{3}\right)_{3}\right), 14.1\left(\mathrm{CH}_{3}\right), 14.0 \mathrm{ppm}\left(\mathrm{CH}_{3}\right) ;$ MS (MALDI): $\mathrm{m} / \mathrm{z}$ calcd for $\mathrm{C}_{148} \mathrm{H}_{86} \mathrm{~N}_{7} \mathrm{O}_{19}{ }^{+}[\mathrm{M}+\mathrm{H}]^{+}$, 2264.6; found: 2265; HRMS (ESI-TOF): $\mathrm{m} / \mathrm{z}$ calcd for $\mathrm{C}_{148} \mathrm{H}_{85} \mathrm{~N}_{7} \mathrm{O}_{19} \mathrm{Na}^{+}[M+\mathrm{Na}]^{+}:$2286.5792; found: 2286.5749 .

\section{Acknowledgements}

The authors thank Ms. Marina G. Pyshnyak and Mr. Ilya V. Shaytor for their help in measuring UV/Vis and nanosecond transient absorption spectra. We gratefully acknowledge the financial support of the Russian Foundation for Basic Research (Grant No. 14-03-00187) and St. Petersburg State University (Grant No. 12.38.78.2012). A.S.K. acknowledges a DAAD-St. Petersburg State University fellowship (A1178335/12.23.508.2012). A.S.M. also acknowledges St. Petersburg State University for financial support (postdoctoral fellowship \#12.50.1562.2013). This research used resources of the resource center "Computer Center", "Research Resource Center for Magnetic Resonance",
"Center for Chemical Analysis and Material Research", "Center for Optical and Laser Materials Research", and "Educational Resource Chemical Center" of St. Petersburg State University.

Keywords: charge transfer - density functional calculations dipolar cycloaddition $\cdot$ fullerenes $\cdot$ ylides

[1] a) P. Liddell, J.P. Sumida, A. N. Macpherson, L. Noss, G. R. Seely, K. N. Clark, A. L. Moore, T. A. Moore, D. Gust, Photochem. Photobiol. 1994, 60, 537-541; b) H. Imahori, Org. Biomol. Chem. 2004, 2, 1425-1433; c) D. M. Guldi, Chem. Soc. Rev. 2002, 31, 22-36; d) N. Martín, Chem. Commun. 2006, 2093-2104.

[2] a) D. M. Guldi, Phys. Chem. Chem. Phys. 2007, 9, 1400-1420; b) H. Imahori, T. Umeyama, K. Kurotobi, Y. Takano, Chem. Commun. 2012, 48, 4032-4045; c) Sh. Fukuzumi, K. Ohkubo, Dalton Trans. 2013, 42, $15846-15858$.

[3] For a discussion of the role of intramolecular exciplex formation, see: $\mathrm{H}$. Lemmetyinen, N. Tkachenko, A. Efimov, M. Niemi, J. Porphyrins Phthalocyanines 2009, 13, 1090-1097.

[4] H. Imahori, K. Tamaki, D. M. Guldi, C. Luo, M. Fujitsuka, O. Ito, Y. Sakata, Sh. Fukuzumi, J. Am. Chem. Soc. 2001, 123, 2607-2617.

[5] R. A. Marcus, N. Sutin, Biochim. Biophys. Acta Rev. Bioenerg. 1985, 811, 265-322.

[6] a) H. Yamada, K. Ohkubo, D. Kuzuhara, T. Takahashi, A. S. D. Sandanayaka, T. Okujima, K. Ohara, O. Ito, H. Uno, N. Ono, Sh. Fukuzumi, J. Phys. Chem. B 2010, 114, 14717-14728; b) A. S. Konev, A. F. Khlebnikov, T. G. Nikiforova, A. A. Virtsev, H. Frauendorf, J. Org. Chem. 2013, 78, $2542-$ 2552.

[7] a) N. V. Tkachenko, H. Lemmetyinen, J. Sonoda, K. Ohkubo, T. Sato, H. Imahori, Sh. Fukuzumi, J. Phys. Chem. A 2003, 107, 8834-8844; b) Y. Shibano, M. Sasaki, H. Tsuji, Y. Araki, O. Ito, K. Tamao, J. Organomet. Chem. 2007, 692, 356-367; c) M. Sasaki, Y. Shibano, H. Tsuji, Y. Araki, K. Tamao, O. Ito, J. Phys. Chem. A 2007, 111, 2973-2979; d) T. J. Kesti, N. V. Tkachenko, V. Vehmanen, H. Yamada, H. Imahori, Sh. Fukuzumi, H. Lemmetyinen, J. Am. Chem. Soc. 2002, 124, 8067-8077; e) D. I. Schuster, Sh. MacMahon, D. M. Guldi, L. Echegoyen, S. E. Braslavsky, Tetrahedron 2006, 62, 1928-1936; f) H. Imahori, K. Tamaki, Y. Araki, T. Hasobe, O. Ito, A. Shimomura, S. Kundu, T. Okada, Y. Sakata, Sh. Fukuzumi, J. Phys. Chem. A 2002, 106, 2803-2814; g) K. Yamanaka, M. Fujitsuka, Y. Araki, K. Tashiro, A. Sato, T. Yuzawa, T. Aida, J. Porphyrins Phthalocyanines 2007, 11, $397-405$; h) D. I. Schuster, K. Li, D. M. Guldi, A. Palkar, L. Echegoyen, Ch. Stanisky, R. J. Cross, M. Niemi, N. V. Tkachenko, H. Lemmetyinen, J. Am. Chem. Soc. 2007, 129, 15973-15982; i) A. Lembo, P. Tagliatesta, D. M. Guldi, M. Wielopolski, M. Nuccetelli, J. Phys. Chem. A 2009, 113, $1779-1793$.

[8] a) D. I. Schuster, Carbon 2000, 38, 1607-1614; b) D. M. Guldi, Ch. Luo, M. Prato, A. Troisi, F. Zerbetto, M. Scheloske, E. Dietel, W. Bauer, A. Hirsch, J. Am. Chem. Soc. 2001, 123, 9166-9167.

[9] a) D. I. Schuster, P. Cheng, P. D. Jarowski, D. M. Guldi, Ch. Luo, L. Echegoyen, S. Pyo, A. R. Holzwarth, S. E. Braslavsky, R. M. Williams, G. Klihm, J. Am. Chem. Soc. 2004, 126, 7257-7270; b) S. A. Vail, D. I. Schuster, D. M. Guldi, M. Isosomppi, N. Tkachenko, H. Lemmetyinen, A. Palkar, L. Echegoyen, X. Chen, J. Z. H. Zhang, J. Phys. Chem. B 2006, 110, 1415514166.

[10] a) E. Krokos, F. Spänig, M. Ruppert, A. Hirsch, D. M. Guldi, Chem. Eur. J. 2012, 18, 10427-10435; b) E. Krokos, F. Spänig, M. Ruppert, A. Hirsch, D. M. Guldi, Chem. Eur. J. 2012, 18, 1328-1341.

[11] A. H. Al-Subi, M. Niemi, N. V. Tkachenko, H. Lemmetyinen, J. Phys. Chem. A 2011, 115, 3263-3271.

[12] E. Krokos, Ch. Schubert, F. Spänig, M. Ruppert, A. Hirsch, D. M. Guldi, Chem. Asian J. 2012, 7, 1451-1459.

[13] S. Schlundt, G. Kuzmanich, F. Spänig, G. de Miguel Rojas, Ch. Kovacs, M. A. Garcia-Garibay, D. M. Guldi, A. Hirsch, Chem. Eur. J. 2009, 15, $12223-12233$.

[14] V. Chukharev, N. V. Tkachenko, A. Efimov, D. M. Guldi, A. Hirsch, M. Scheloske, H. Lemmetyinen, J. Phys. Chem. B 2004, 108, 16377-16385.

[15] a) D. M. Guldi, Ch. Luo, M. Prato, E. Dietel, A. Hirsch, Chem. Commun. $2000,373-374$; b) for unusual stabilization of the CS state in close-contact porphyrin-fullerenes in the case of Co", see: L. R. Sutton, M. Sche- 
loske, K. S. Pirner, A. Hirsch, D. M. Guldi, J.-P. Gisselbrecht, J. Am. Chem. Soc. 2004, 126, 10370-10381; c) A. H. Al-Subi, M. Niemi, N. V. Tkachenko, H. Lemmetyinen, J. Phys. Chem. A 2012, 116, 9653-9661.

[16] a) M. E. El-Khouly, K.-J. Han, K.-Y. Kay, S. Fukuzumi, ChemPhysChem 2010, 11, 1726-1734; b) F. D'Souza, S. Gadde, D.-M. Sh. Islam, Ch. A. Wijesinghe, A. L. Schumacher, M. E. Zandler, Y. Araki, O. Ito, J. Phys. Chem. A 2007, 111, 8552-8560.

[17] Y. Kobori, Y. Shibano, Ts. Endo, H. Tsuji, H. Murai, K. Tamao, J. Am. Chem. Soc. 2009, 131, 1624-1625.

[18] a) D. Kuciauskas, S. Lin, G. R. Seely, A. L. Moore, Th. A. Moore, D. Gust, T. Drovetskaya, Ch. A. Reed, P. D. W. Boyd, J. Phys. Chem. 1996, 100 15926-15932; b) F. D'Souza, E. Maligaspe, P. A. Karr, A. L. Schumacher M. El Ojaimi, C. P. Gros, J.-M. Barbe, K. Ohkubo, Sh. Fukuzumi, Chem. Eur J. 2008, 14, 674-681; c) A. Ciammaichella, P. O. Dral, T. Clark, P. Tagliatesta, M. Sekita, D. M. Guldi, Chem. Eur. J. 2012, 18, 14008-14016.

[19] a) V. Vehmanen, N. V. Tkachenko, H. Imahori, Sh. Fukuzumi, H. Lemmetyinen, Spectrochim. Acta Part A 2001, 57, 2229-2244; b) F.-P. Montforts, I. Vlassiouk, S. Smirnov, M. Wedel, J. Porphyrins Phthalocyanines 2003, 7, $651-666$; c) M. E. El-Khouly, Y. Araki, O. Ito, S. Gadde, A. L. McCarty, P. A. Karr, M. E. Zandler, F. D'Souza, Phys. Chem. Chem. Phys. 2005, 7, $3163-$ 3171; d) S. Campidelli, R. Deschenaux, A. Swartz, G. M. A. Rahman, D. M. Guldi, D. Milic, E. Vázquez, M. Prato, Photochem. Photobiol. Sci. 2006, 5 1137-1141; e) H. Tsuji, M. Sasaki, Y. Shibano, M. Toganoh, T. Kataoka, Y. Araki, K. Tamao, O. Ito, Bull. Chem. Soc. Jpn. 2006, 79, 1338-1346 f) M. E. El-Khouly, J. Hasegawa, A. Momotake, M. Sasaki, Y. Arakia, O. Ito T. Arai, J. Porphyrins Phthalocyanines 2006, 10, 1380-1391; g) T. D. M. Bell, K. P. Ghiggino, A. Haynes, S. J. Langford, C. P. Woodward, J. Porphyrins Phthalocyanines 2007, 11, 455-462; h) J. lehl, M. Vartanian, M Holler, J.-F. Nierengarten, B. Delavaux-Nicot, J.-M. Strub, A. Van Dorsselaer, Y. Wu, J. Mohanraj, K. Yoosaf, N. Armaroli, J. Mater. Chem. 2011, 21 $1562-1573$; i) F. Oswald, D.-M. Sh. Islam, M. E. El-Khouly, Y. Araki, R. Caballero, P. de La Cruz, O. Ito, F. Langa, Phys. Chem. Chem. Phys. 2014, 16, 2443-2451.

[20] a) S. A. Vail, P. J. Krawczuk, D. M. Guldi, A. Palkar, L. Echegoyen, J. P. C. Tomé, M. A. Fazio, D. I. Schuster, Chem. Eur. J. 2005, 11, 3375-3388 b) A. Lembo, P. Tagliatesta, D. M. Guldi, J. Phys. Chem. A 2006, 110 $11424-11434$.

[21] B. Boëns, P.-A. Faugeras, J. Vergnaud, R. Lucas, K. Teste, R. Zerrouki, Tetrahedron 2010, 66, 1994-1996.

[22] G. R. Geier, J. S. Lindsey, Tetrahedron 2004, 60, 11435-11444.

[23] a) R. Huisgen, W. Scheer, H. Huber, J. Am. Chem. Soc. 1967, 89, $1753-$ 1755 ; b) A. S. Konev, A. F. Khlebnikov, H. Frauendorf, J. Org. Chem. 2011,
76, 6218-6229; c) A. S. Konev, A. A. Mitichkina, A. F. Khlebnikov, H. Frauendorf, Russ. Chem. Bull. 2012, 61, 863-870.

[24] a) N. De Kimpe, R. Verhé, L. De Buyck, N. Schamp, J. Org. Chem. 1980 45, 5319-5325; b) K. G. Rasmussen, K. A. Jørgensen, J. Chem. Soc. Perkin Trans. 1 1997, 1287-1291; c) M. F. Mayer, M. M. Hossain, J. Org. Chem. 1998, 63, 6839-6844.

[25] a) W. Xie, J. Fang, J. Li, P. G. Wang, Tetrahedron 1999, 55, 12929-12938 b) A. F. Khlebnikov, M. S. Novikov, M. V. Golovkina, P. P. Petrovskii, A. S. Konev, D. S. Yufit, H. Stoeckli-Evans, Org. Biomol. Chem. 2011, 9, $3886-$ 3895.

[26] a) M. Sun, P. Song, Y. Chen, F. Ma, Chem. Phys. Lett. 2005, 416, 94-99; b) M. E. Zandler, F. D'Souza, C. R. Chim. 2006, 9, 960-981; c) O. Cramariuc, T. I. Hukka, T. T. Rantala, H. Lemmetyinen, J. Phys. Chem. A 2006, 110, 12470-12476; d) T. L. J. Toivonen, T. I. Hukka, Chem. Phys. Lett. 2007, 444, 107-112; e) O. E. Kvyatkovskii, E. G. Donenko, I. B. Zakharova, Fullerenes Nanotubes Carbon Nanost. 2008, 16, 530-533; f) Sh. Zhang, Y. Li, J. Liu, M. Zhao, Y. Han, Y. Ding, P. Song, F. Ma, Int. J. Photoenergy 2012, 314896; g) A. S. Shalabi, S. Abdel Aal, A. M. El Mahdy, Molecular Simulation 2013, 39, 689-699.

[27] For literature examples of the heavy atom effect of bromine, see: a) J. B. Kim, J. J. Leonard, F. R. Longo, J. Am. Chem. Soc. 1972, 94, $3986-$ 3992 ; b) J. Saltiel, D. W.-L. Chang, E. Dennis Megarity, J. Am. Chem. Soc. 1974, 96, 6521-6522; c) A. K. Chandra, N. J. Turro, A. L. Lyons Jr., P. Stone, J. Am. Chem. Soc. 1978, 100, 4964-4968; d) V. A. Ganzha, G. P. Gurinovich, B. M. Dzhagarov, G. D. Egorova, E. I. Sagun, A. M. Shul'ga, J. Appl. Spectrosc. 1989, 50, 402-406; e) M. Rae, F. Perez-Balderas, C. Baleizão, A. Fedorov, J. A. S. Cavaleiro, A. C. Tomé, M. N. Berberan-Santos, J. Phys. Chem. B 2006, 110, 12809-12814; f) F. Gao, X. Wang, S. Wang, M. Liu, X. Liu, X. Ye, H. Li, Tetrahedron 2013, 69, 2720-2732.

[28] For an example of correction for the solvent effect according to the Rehm - Weller equation (D. Rehm, A. Weller, Isr. J. Chem. 1970, 8, 259) in supramolecular porphyrin $-C_{60}$ complexes, see: F. D'Souza, R. Chitta, S. Gadde, M. E. Zandler, A. L. McCarty, A. S. D. Sandanayaka, Y. Araki, O. Ito, J. Phys. Chem. A 2006, 110, 4338-4347.

[29] A. S. Konev, D. A. Lukyanov, P. S. Vlasov, O. V. Levin, A. A. Virtsev, I. M. Kislyakov, A. F. Khlebnikov, Macromol. Chem. Phys. 2014, 215, 516-529.

[30] M. von Georg, J. Klawitter, Die Makromoleculare Chemie 1971, 142, 253 257.

Received: July 16, 2014

Published online on November 7, 2014 